\title{
Wood-based diet and gut microflora of a galatheid crab associated with Pacific deep-sea wood falls
}

\author{
Caroline Hoyoux $\cdot$ Magali Zbinden $\cdot$ Sarah Samadi $\cdot$ \\ Françoise Gaill $\cdot$ Philippe Compère
}

Received: 18 August 2008 / Accepted: 19 July 2009 / Published online: 16 September 2009

(C) Springer-Verlag 2009

\begin{abstract}
Wood falls in the deep sea have recently become the focus of studies showing their importance as nutrients on the deep-sea floor. In such environments, Crustaceans constitute numerically the second-largest group after Mollusks. Many questions have arisen regarding their trophic role therein. A careful examination of the feeding appendages, gut contents, and gut lining of Munidopsis andamanica caught with wood falls revealed this species as a truly original detritivorous species using wood and the biofilm covering it as two main food sources. Comparing individuals from other geographic areas from substrates not reported highlights the galatheid crab as specialist of refractory substrates, especially vegetal remains. $M$. andamanica also exhibits a resident gut microflora consisting of bacteria and fungi possibly involved in the digestion of wood fragments. The results suggest that Crustaceans could be fullfledged actors in the food chains of sunken-wood ecosystems and that feeding habits of some squat lobsters could be different than scavenging.
\end{abstract}

Communicated by S. A. Poulet.

C. Hoyoux $(\bowtie) \cdot$ P. Compère

Laboratoire de Morphologie fonctionnelle et évolutive,

Unité de Morphologie Ultrastructurale, Université de Liège,

Allée de la Chimie, 3, 4000 Liège, Belgium

e-mail: Caroline.Hoyoux@ulg.ac.be

M. Zbinden $\cdot$ F. Gaill

UMR 7138 CNRS, Université Pierre et Marie Curie,

72252 Paris Cedex 05, France

S. Samadi

UMR 7138 UPMC-IRD-MNHN-CNRS,

CP 26, 57 Rue Cuvier, Muséum National d'Histoire Naturelle,

75231 Paris cedex 05, France

\section{Introduction}

Today, wood falls are the focus of much research and many oceanographic cruises. They are regarded as sulfide-rich reducing environments $\left(\mathrm{H}_{2} \mathrm{~S}>50 \mu \mathrm{M}\right.$; Smith et al. 2003) along with whale falls, hydrothermal vents, and cold seeps. Wood falls are also seen as huge, unexpected food sources on the deep-sea floor, possibly having fundamental importance in the nutritional ecology of deep oceans (Cayré and Richer de Forges 2002, Smith et al. 2003, Palacios et al. 2006). Twenty-five years after publishing the first detailed lists of species associated to deep-sea wood falls by Turner (1977) and Wolff (1979), the BOA1 cruise report (Samadi et al. 2005) showed that sunken wood ecosystems support a richly diversified fauna of macroinvertebrates. Mollusks form the first group in terms of both diversity and number of individuals represented mainly by wood-borer teredinid bivalves as well as by mytilids and limpets firmly attached to the wood. The group has received a careful attention since the 1980s in the description of the animal communities (e.g. Marshall 1985, 1988; Kiel and Goedert 2006a, b; Pailleret et al. 2006), as well as in the study of the impressive taxonomic diversity of mussels (Samadi et al. 2007; Lorion et al. 2009). Moreover, the phylogenetic relationships among wood-, bone-, vent-, and seep-associated mussels led to propose the "stepping stones" hypothesis for the colonization of the deep-sea reducing environments (see Smith et al. 1989; Distel et al. 2000). Crustaceans constitute the second-largest zoological group in deep-sea wood falls, with many species of decapods as galatheid squat lobsters, pagurid hermit crabs and thalassinid shrimps, as well as with species of amphipods and isopods. Apart from their taxonomies, almost nothing else is known about these crustaceans.

Among the decapods, the squat lobster Munidopsis andamanica MacGilchrist, 1905 is numerically one of the 
most represented species. Several recent cruises (BOA12005, SantoBOA-2006, SalomonBOA3-2007) have confirmed its regular association to deep-sea wood falls. Individuals are commonly found on the surface of the sunken wood pieces. However, nothing is known about its diet and trophic dependency to wood or to the wood fall ecosystem. Does it feed directly on wood or does it scavenge or practice predation on other organisms associated to it? In addition, since sunken woods are not only refractory substrates (i.e. containing cellulose, lignin) but also reducing chemosynthetic-based ecosystems, does $M$. andamanica realize symbiotic associations with microorganisms, either to digest wood or to exploit reducing compounds as energy sources? Is it specifically associated to sunken wood or not? Indeed, $M$. andamanica were previously collected in other locations and perhaps on other substrates (not reported): in the Andaman Sea, along the west coast of Sumatra, and in the waters of the Moluccas, the Philippines, the South China Sea (Baba 1988), Taiwan (Wu et al. 1998), Indonesia, the Solomon Islands, New Caledonia, and the Vanuatu and Fiji Islands, at depths of 333-1,598 m (Macpherson 2007).

On the other hand, the genus Munidopsis Whiteaves, 1874 is distributed worldwide in all deep-sea habitats and commonly found living deeper than $500 \mathrm{~m}$, and down to 2,000 m, on continental slopes and abyssal plains (Baba 1988, 2005; Macpherson and Segonzac 2005). Interestingly, their presence is also reported in vent- and coldseep communities (Williams 1988; Hashimoto et al. 1995; Chevaldonné and Olu 1996), as well as on whale and wood falls (Bennett et al. 1994; Goffredi et al. 2004; Samadi et al. 2005). Although few studies focused on their diet, they are commonly thought to be scavengers while their feeding habits are much diversified and not clearly established. Some species from hydrothermal vents, such as $M$. marionis, $M$. acutispina and another Munidopsis sp. (complete name is not mentioned) would be predators or scavengers (Chevaldonné and Olu 1996; Macavoy et al. 2008a) while M. alvisca, M. subsquamosa, M. geyeri and another Munidopsis sp. appeared to have a mixed diet composed of organic debris of the sediment, polychaetes, limpets, crab larvae, and would also graze the bacteria of the biofilms (Van Dover and Lichtwardt 1986; Escobar-Briones et al. 2002; Micheli et al. 2002; Phleger et al. 2005). Nothing is reported about the diet of M. cascadia, M. yaquiensis, M. verrilli, and M. quadrata that are found associated to whale carcasses (Williams et al. 2000). However, experimental studies showed that M. crassa and another Munidopsis sp. would be scavengers of bone remnants (Janßen et al. 2000; Kemp et al. 2006; Macavoy et al. 2008b). In addition, other species (M. serricornis, M. sarissa) were found in gorgonians or sponges, and would perhaps feed on the organic matter or even on the tissues of these organisms (Macpherson and Segonzac 2005).

The aim of the present study was to describe and specify the diet of the $M$. andamanica specimens associated to wood falls from Vanuatu, in order to have a better understanding about the role they play in these particular ecosystems. In addition, comparisons with specimens from five other geographic areas were carried out to determine whether M. andamanica is a specialist of sunken woods or an opportunistic generalist with various food sources, as commonly admitted for squat lobsters.

We also looked for microorganisms in the digestive tract in order to determine whether the specimens of $M$. andamanica have developed digestive and/or chemosynthetic microbial symbioses. Indeed, previous studies have highlighted chemosynthetic bacterial symbioses in the branchial tissues of bivalves from wood falls (Distel and Roberts 1997; Gros and Gaill 2007; Duperron et al. 2008), and the digestion of vegetal cells often implies a heterotrophic gut microflora providing the host with exoenzymes for metabolizing constituents of plant cell walls; such associations are well known in xylophagous insects (Foglesong et al. 1975; Potrikus and Breznak 1977; Bayon 1980; Bignell 1984; Margulis et al. 1990; Zurek and Keddie 1998; Dolan 2001).

\section{Materials and methods}

\section{Biological material}

Specimens of $M$. andamanica associated to wood falls were collected off Vanuatu Islands during the BOA1 cruise (September 2005, Vanuatu) and during the SantoBOA cruise (October 2006) on the R/V Alis. During these cruises the large bay (Big Bay) located at the north of Espiritu Santo Island in Vanuatu was thoroughly explored by trawling. Over the two cruises 55 stations were explored in this bay at depth ranging from 150 to $1,000 \mathrm{~m}$. Most of the time, trawl brought back sunken woods and other plant debris. The sunken plant material was always associated to a specific fauna. Among other organisms, wood-boring bivalves of the genus Xyloph$a g a$, wood-eating limpets of the genus Pectinodonta and wood or reed housing hermit crabs of the genus Xylopagurus were very abundant. During these cruises $M$. andamanica were repeatedly caught in relatively great number together with woods, other plant debris and the typical associated fauna. We here examined six specimens from the wood falls of Vanuatu: four from the station CP2432 (14 ${ }^{\circ} 59.7^{\prime} \mathrm{S}, 166^{\circ} 55.0^{\prime} \mathrm{E}, 630-705 \mathrm{~m}, 08$ Sep 2005, BOA1), one from the station CP2421 $\left(14^{\circ} 57.1^{\prime} \mathrm{S}, 166^{\circ} 55.1^{\prime} \mathrm{E}, 677-771 \mathrm{~m}, 06\right.$ Sep 2005, 
BOA1) and one from the station AT90 $\left(15^{\circ} 01.5^{\prime} \mathrm{S}\right.$, $166^{\circ} 54.1^{\prime} \mathrm{E}, 503-553 \mathrm{~m}, 13$ Oct 2006, SantoBOA). We compare these specimens with three individuals associated to wood falls from Solomon Islands (station CP2846, $10^{\circ} 28.0^{\prime} \mathrm{S}, 161^{\circ} 22.4^{\prime} \mathrm{E}, 533-612 \mathrm{~m}, 23 \mathrm{Sep}$ 2007, SalomonBOA3) and with four specimens from four different geographic areas and possibly recovered on other substrates because the later were not reported. These specimens come from New Caledonia (station CP741, 22 ${ }^{\circ} 36^{\prime} \mathrm{S}, 166^{\circ} 26^{\prime} \mathrm{E}, 700-950 \mathrm{~m}, 1993$, Bathus2), from the Philippines (station CP123, $12^{\circ} 11^{\prime} \mathrm{N}, 121^{\circ} 45^{\prime} \mathrm{E}$, 648-649 m, 1985, Musorstom3), from Indonesia (station $\mathrm{CC} 21,05^{\circ} 14^{\prime} \mathrm{S}, 133^{\circ} 00^{\prime} \mathrm{E}, 688-694 \mathrm{~m}, 1991$, Karubar), and from the Fiji Islands (station CP1342, $16^{\circ} 46.0^{\prime} \mathrm{S}$, $177^{\circ} 39.7^{\prime} \mathrm{E}$, 650-701 m, 1998, Musorstom10). Almost all specimens were fixed and conserved on board in $75^{\circ}$ and used in light microscopy, scanning and/or transmission electron microscopy (LM, SEM, and TEM). The gut of some specimens from Solomon Islands were dissected, removed and fixed in $4 \%$ paraformaldehyde, rinsed, and kept in ethanol $99 \%$ at $4{ }^{\circ} \mathrm{C}$. One of them was used in this study for staining with $4^{\prime}, 6$-diamidino-2phenylindole (DAPI).
Macroscopic observations and dissection

Before preparation for microscopy, the specimens were examined and photographed. During dissection, the position of the digestive system in relation to the body was drawn in broad outline (Fig. 1a), with the help of a camera Lucida on a Leica M10 stereomicroscope. For microscopy, the following dissections were performed with flame-sterilized instruments. Mouthparts were removed and separated in order to have complete details of their external morphology. Digestive tracts were dissected and divided into three parts: the foregut, the anterior intestinal region, and the posterior intestinal region. This division was arbitrary, as no particular external morphology enabled us to distinguish the midgut from the hindgut. Because ethanol fixation tends to weaken tissues, the midgut often broke off during dissection. It appeared very short, just behind the stomach.

\section{SEM and X-ray microanalysis}

Scanning electron microscopy (SEM) was used to observe the digestive tracts of five specimens from Vanuatu (4 from the BOA1 cruise and 1 from the SantoBOA cruise), and the
Fig. 1 Munidopsis andamanica. Ethanol-preserved specimen from a deep-sea sunken wood (BOA1 cruise, Vanuatu). a Diagram of the digestive tract. The midgut is supposed to be very short or lost because never observed. Anterior and posterior parts of the hindgut are not externally different and were dissected arbitrary. b Dorsal view of the specimen. c Spoon-shaped depression formed by a closed-up claw. d SEM view of the tip of the cheliped finger: serrated edge and clumps of large, smooth setae
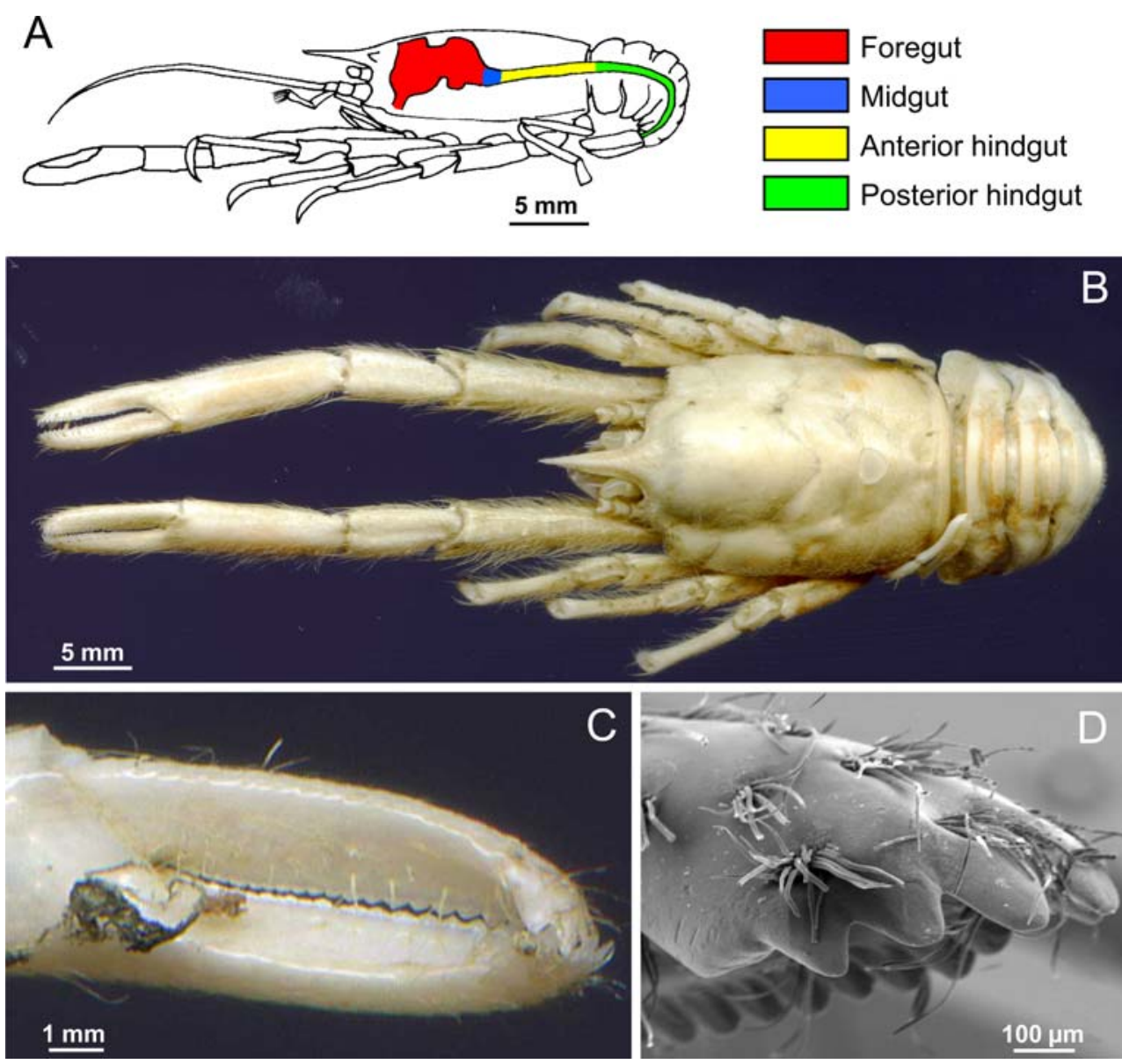
digestive tract of specimens from the Solomon Islands, Philippines, New Caledonia, Fiji Islands and Indonesia. The hindgut of the SantoBOA-cruise specimen was divided into four parts: two for observation in SEM and two for observation in TEM and LM (see below). Mouthparts and gut samples of a specimen from Vanuatu were dehydrated through a graded ethanol series, critical-point dried with $\mathrm{CO}_{2}$ as the transitional fluid, and mounted on aluminum stubs. During mounting, the different parts of the gut were split longitudinally to reveal the gut lining morphology. The gut contents were gently removed and put next to the digestive structure that initially contained them. When they were recognizable beneath the stereomicroscope, constituents of the gut contents were roughly identified. The samples were finally platinum-coated in a Balzers SCD-030 sputter-unit prior to observation with a scanning microscope (JEOL JSM-840A) operating at $20 \mathrm{kV}$.

Elemental energy-dispersive X-ray microanalyses (EDX) were performed on the platinum-coated bulk samples prepared for SEM observation, to determine the elemental composition of hard mineral pieces in the gut content. X-ray microanalyses and elemental spectra were performed with a scanning electron microscope fitted with a Link Pentafet detector and a Link eXl-10 analyzer.

\section{LM and TEM}

Fixed on board in $70^{\circ}$ ethanol during the BOA1 and SantoBOA cruises, the gut of one BOA1-cruise specimen and the two other parts of the hindgut of the SantoBOAcruise specimen were utilized for light microscopy (LM) and transmission electron microscopy (TEM). For better preservation of the tissue during processing, they were re-hydrated in the laboratory and fixed in $2.5 \%$ glutaraldehyde in seawater diluted $7 / 10$. Then the gut samples were rinsed, fixed in $1 \% \mathrm{OsO}_{4}$, dehydrated through an ethanol and propylene oxide series, and embedded in epoxy resin (SPI-PON 812). Semi-thin and ultra-thin sections were obtained with a Reichert-Jung Ultramicrotome (Ultracut E) using a diamond knife. Semi-thin sections were stained with toluidine blue (1\%, $\mathrm{pH} 9.0)$ for observation by light microscopy (with an Olympus PROVIS AX70) and photographed with an Olympus DP50-CU camera. Ultra-thin sections were contrasted with uranium acetate and lead citrate and observed with a Jeol (JEM 100-SX) transmission electron microscope operating at $80 \mathrm{kV}$.

\section{DAPI staining}

The gut of one specimen from Solomon Islands was fixed in $4 \%$ PFA, kept in $100 \%$ ethanol and embedded in
Steedman's wax [polyethylene glycol distearate (PEG): 1-hexadecanol 9:1]. Sections of $8 \mu \mathrm{m}$ were obtained with a Reichert-Austria Microtome on Superfrost Ultra Plus slides and conserved at $-20^{\circ} \mathrm{C}$. The slides were passed through three successive $100 \%$ ethanol baths to remove the wax and dried, then passed through $75 \%$ ethanol and re-dried, and finally passed in methanol: acetic acid (1:3) to permeabilize the bacteria before to be dried again. The DAPI solution $(0.5 \mu \mathrm{g} / \mathrm{ml})$ was applied on the sections for $15 \mathrm{~min}$ in the dark, and then the slides were rinsed in distilled water and observed with an epifluorescence microscope.

\section{Results}

Morphological features of feeding appendages and claws

As shown on the specimen in Fig. 1b, M. andamanica has symmetrical, long (twice the length of the carapace), and thin, spindly but robust chelipeds. As a reminder, the pereiopods of crustaceans classically consist of seven segments: coxa, basis, ischium, merus, carpus, propodus, and dactylus. The claws are formed by articulation of the dactylus with an outgrowth of the propodus.

In resting position, the chelipeds of $M$. andamanica are outstretched forward with the claws laid in such a way that they can pinch laterally and are dorsoventrally flattened. The mediodorsal rims of the fingers bear a row of sharp teeth that grow serrated toward the distal part of each finger and become a smooth edge in the ventral rim. When the fingers are closed, the mediodorsal rims meet each other; the serrated edges show imbricated teeth and the ventral side of each claw forms a spoon-shaped depression (Fig. 1c). The chelipeds are covered with many clumps of large, smooth setae without epibiotic microorganisms (Fig. 1d). The joints between the propodus and carpus, and between the carpus and merus enable movements of the claws toward the mouth appendages.

As in other decapods, the mouthparts consist of six pairs of appendages. From oral to aboral these are: the mandibles, the first and second maxillae, and the first, second, and third maxillipeds. A general view of the mouthparts of $M$. andamanica is shown in Fig. 2a. All mouthparts were observed, but we present here only the results pertaining to the third maxillipeds, the first maxillae, and the mandibles, because several previous studies on decapods have shown that the third maxillipeds are often the first parts to make contact with the food (accumulating sediment, collecting particles in suspension, or grasping preys) and that the crista dentata, a raw of strong teeth on the ischiopodite of the third maxilliped, can sometimes play a role in clasping large food items. The food is generally transferred from the 

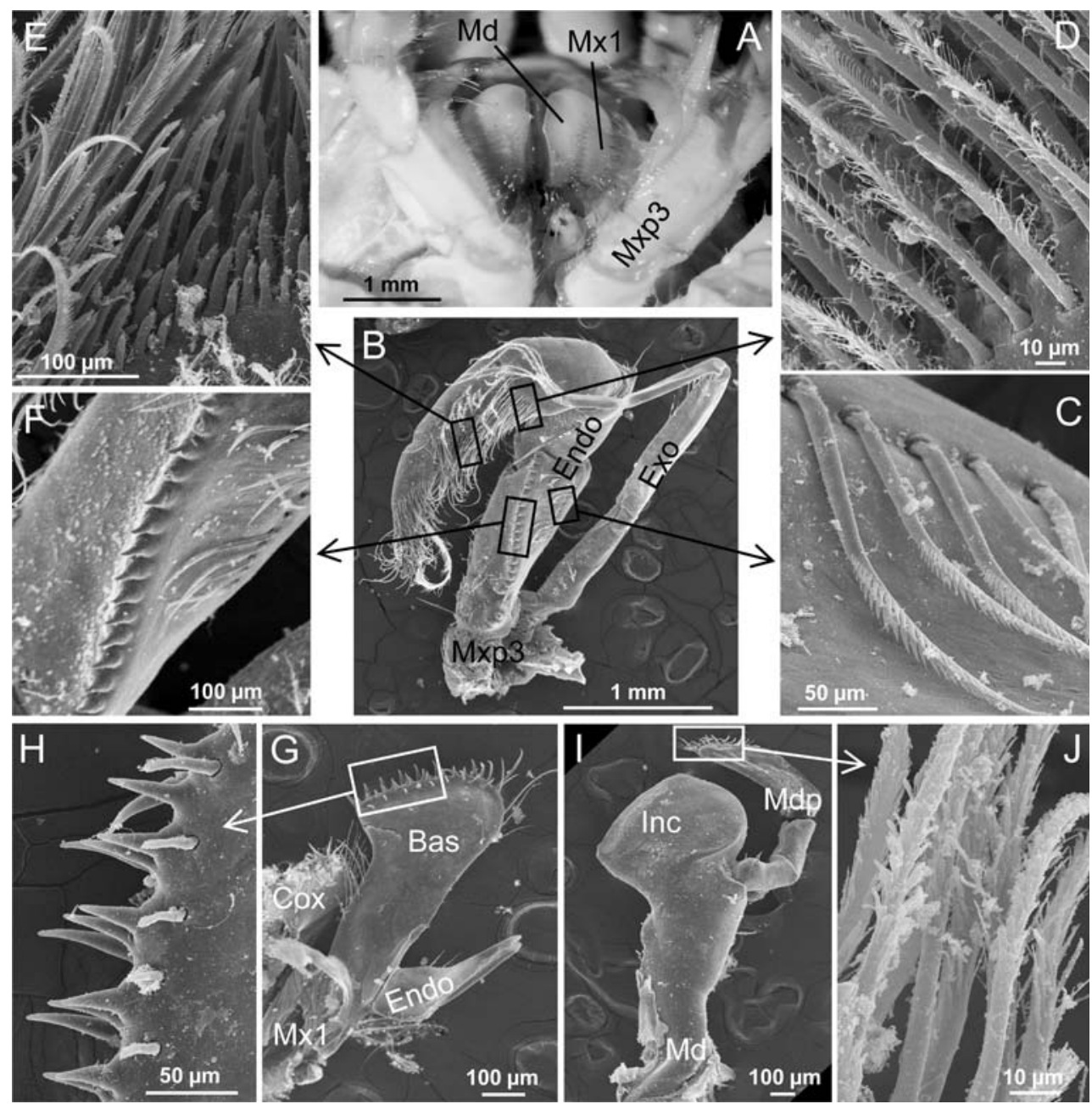

Fig. 2 Munidopsis andamanica from Vanuatu. Mouthparts. a Ventral view of the mouthparts, $\mathbf{b}-\mathbf{f}$ general view and details of the left third maxilliped, $\mathbf{c}$ serrate setae on the ischiopodite, $\mathbf{d}$ papposerrate setae carpopodite, $\mathbf{e}$ serrate setae on the propodite, $\mathbf{f}$ strong crista dentata on the ischiopodite, $\mathbf{g}, \mathbf{h}$ left first maxilla, with (h) spines and teeth-like cuspidate setae on the basipodite, $\mathbf{i}, \mathbf{j}$ left mandible with (j) thick serrate setae with scale-like setules on the pedipalp. Bas basipodite, Cox coxopodite, Endo endopodite, Exo exopodite, Inc incisor process, $M d$ mandible, $M d p$ mandible pedipalp, Mxl first maxilla, Mxp3 third maxilliped

\section{Third maxillipeds}

Each third maxilliped of M. andamanica (Fig. 2b) consists of a basis bearing a segmented pediform endopodite and a long, slender, segmented exopodite with few setae. The endopodite is composed of an ischiopodite with an aboral row of ten large serrate setae (Fig. 2c), a meropodite with seven strong simple setae, a carpopodite with fine long papposerrate setae (Fig. 2d), a propodite with short pappose setae on the aboral side and long, fine, serrate setae on the oral side (Fig. 2e), and a small dactylopodite with bundles of long serrate setae. The medio-oral side of the ischiopodite has a well-developed crista dentata (Fig. 2f) with a row of 18 strong teeth $70-80-\mu \mathrm{m}$ height with tip-to-tip distances of $\pm 60 \mu \mathrm{m}$. 


\section{First maxillae}

Each first maxilla of $M$. andamanica (Fig. $2 \mathrm{~g}$ ) consists of a paddle-shaped basipodite, a coxopodite, and a spike-heellike endopodite. Only the basipodite has large spines and large teeth-like cuspidate setae on the medial side (Fig. 2h).

\section{Mandibles}

Each mandible of $M$. andamanica (Fig. $2 \mathrm{i}$ ) consists of a long basis bearing a gnathal lobe and a palp. The gnathal lobe is strongly curved and has two processes: a large, flattened, molar process orally and a large, cutting, incisor process aborally. The palp is three-segmented and originates anteriorly at the base of the gnathal lobe. It crooks to the median and the terminal segment is located orally in relation to the incisor process. The end of the terminal segment bears a bundle of long, large setae of two types; on the one hand, papposerrate setae with sparse fine setules on the distal portion giving way to more densely arranged distal setules, and on the other hand setae with thick, densely arranged scale-like setules (Fig. 2j).

Ultrastructure of the digestive lining

\section{Gastric mill}

The following descriptions concern the grinding pieces of the gastric mill in the foregut, i.e. the dorsal (or median) tooth and lateral teeth. For a description of the anatomy and physiology of the decapod foregut see Ceccaldi (2006).

The dorsal tooth of M. andamanica (Fig. 3a) is smooth and pyramid-shaped, with a rectangular base and triangular lateral surfaces. The anterior face is rather concave and has a dorso-ventral flattened keel. The ventral surface of the urocardiac ossicle leading to the tooth is slightly curved and bears dorso-ventral grooves. Both of the lateral sides of the urocardiac ossicle are girded with setae and the areas from which the tooth arises widen in a small flange bearing spines. Both of the lateral teeth are elongate and oval in shape (Fig. 3b), tapering posteriorly, with nine denticles,
Fig. 3 Munidopsis andamanica from Vanuatu. a-d Gastric mill: a dorsal robust median tooth, b oval-shaped lateral tooth, with (c) projections of short thick spines in its grooves, d lateral accessory tooth with strong spines. e, f Hindgut: e spiny villous plates separated by deep grooves, $\mathbf{f}$ cuticular spines on the villous plates and arranged in semi-circles toward the anus. Ant anterior part, arrows resident bacteria
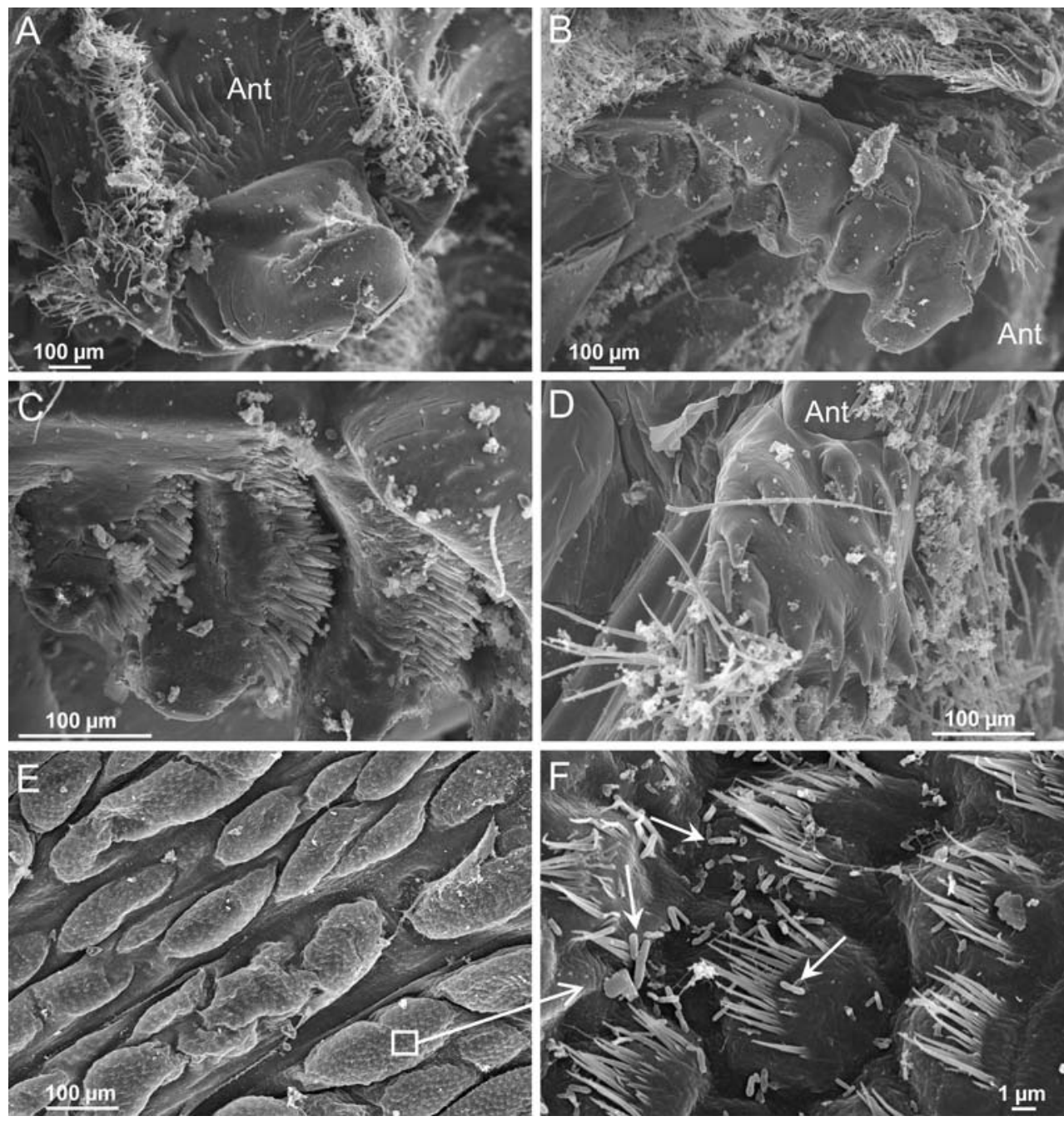
the first anterior denticle being the largest. The first three denticles are smooth and crest-shaped, the fourth being curved. The medial surface of the teeth is concave from this point, and five grooves traverse the teeth posteriorly. They extend to the ventral side of the teeth and are continued on their dorsal side by the last five denticles of the teeth. The three anterior-most grooves have an anterior edge bearing projections of short thick spines (Fig. 3c). Both of the lateral accessory teeth (Fig. 3d) bear 14-15 strong, compact ventral spines arranged in a circle and directed posteriorly.

\section{Midgut and digestive gland}

The midgut and the digestive gland of $M$. andamanica were unfortunately not observed. Due to ethanol fixation, the digestive gland was liquefied and the junction between foregut and hindgut always broke during dissection. Nevertheless, this junction appears very thin, suggesting that the midgut is very short, maybe limited to a simple ring between the pyloric stomach and the anterior hindgut.

\section{Hindgut}

The hindgut of $M$. andamanica has characteristic elliptical villous plates (100-150- $\mu \mathrm{m}$ large, $200-300-\mu \mathrm{m}$ length, and $10-\mu \mathrm{m}$ height; Fig. 3e), except on the ventral zone. Cuticle projections were observed, arranged in acute semi-circles of spines directed toward the anus (Fig. 3f), each semi-circle being formed by one epidermal cell. The anterior-most part of the hindgut has simpler arrangements ( 3 or 5 spines), but the number of spines increases rapidly toward the posterior part. The major part of the hindgut thus bears semi-circles with $12-25$ spines 3 - $\mu \mathrm{m}$ length at their external border and 8-14 spines 500-nm length at their internal border. Between convolutions, however, the number of spines is very low and sometimes nil. The hindgut lining harbors a nanorelief (Figs. 3f, 6c) made of tiny, entwined, rod-shaped paddings $( \pm 1.5-\mu \mathrm{m}$ length $)$ and depressions.

Gut content morphology and X-ray microanalysis

The analyses of the gut contents of all the specimens, including those from the different geographic areas, are summarized in the Table 1 and illustrated by the Figs. 4a-f, $5 \mathrm{a}-\mathrm{g}$, and $6 \mathrm{a}-\mathrm{d}$. Most of the pictures were taken on individuals from wood falls of Vanuatu, but some of them illustrate peculiar structures found in specimens from other locations. The content of the gut always includes both organic and mineral fractions.

In all the specimens associated to the Vanuatu wood falls, LM photographs reveal an organic fraction consisting of large, blue-stained wood fragments (up to $500 \mu \mathrm{m}$ ) mixed with a coarse, purple-stained organic material not readily recognizable (Fig. 4a). The plant fragments exhibit thick secondary walls and empty cell lumens, confirming that they consist of ligneous hard tissue and most probably xylem (Fig. 4b, e). The peripheral broken cells are generally filled with exogenous material (Figs. 4b, e, 5c) and their walls appear considerably decomposed by microorganisms (i.e. bacteria and fungi) (Fig. 4b, f). Bacteria and fungi are observed by SEM on the plant cell walls (Fig. 5a, b). By TEM, these walls appear perforated by tunneling bacteria (Fig. 4f). Low-magnification SEM pictures show that the wood fragments look like shavings rolled up on themselves (Fig. 5c). Almost all specimens from other locations have terrestrial vegetal fragments in their gut contents, except the one from Fiji Islands (Table 1). The specimen associated to wood falls from Solomon Islands has gut content very similar to that of the specimens from Vanuatu wood falls, with high quantities of vegetal fragments of

Table 1 Comparative analysis of the resident hindgut microflora and the gut contents of $14 \mathrm{M}$. andamanica specimens from six different geographic areas: Vanuatu, Solomon Islands, New Caledonia, Fiji Islands, Indonesia, and Philippines

\begin{tabular}{|c|c|c|c|c|c|c|c|c|c|c|c|c|}
\hline \multirow{3}{*}{$\begin{array}{l}\text { Munidopsis } \\
\text { andamanica }\end{array}$} & \multirow[t]{3}{*}{$n$} & \multirow{2}{*}{\multicolumn{2}{|c|}{$\begin{array}{l}\text { Resident } \\
\text { hindgut } \\
\text { microflora }\end{array}$}} & \multicolumn{9}{|c|}{ Gut contents } \\
\hline & & & & \multicolumn{3}{|c|}{ Mineral fraction } & \multicolumn{6}{|c|}{ Organic fraction } \\
\hline & & Bacteria & Fungi & Clay & $\begin{array}{l}\text { Skeletons } \\
\text { and spicules }\end{array}$ & $\begin{array}{l}\text { Tests of } \\
\text { protists }\end{array}$ & $\begin{array}{l}\text { Organic } \\
\text { matter }\end{array}$ & $\begin{array}{l}\text { Plant } \\
\text { remains }\end{array}$ & Algae & Fungi & Gorgonin & Bacteria \\
\hline Vanuatu & 6 & ++++ & +++ & +++ & ++ & +++ & +++ & ++++ & & & & ++++ \\
\hline Solomon & 4 & ++++ & & +++ & ++ & +++ & +++ & ++++ & & & + & ++++ \\
\hline New Caledonia & 1 & ++ & + & +++ & & ++ & +++ & ++ & +++ & +++ & ++ & ++ \\
\hline Fiji & 1 & +++ & & +++ & +++ & ++ & +++ & & & +++ & & +++ \\
\hline Indonesia & 1 & & ++ & ++ & + & +++ & ++ & ++ & +++ & & & ++ \\
\hline Philippines & 1 & +++ & ++ & ++ & +++ & ++ & +++ & +++ & & & ++ & ++++ \\
\hline
\end{tabular}

Approximate proportion of items observed: + rare (15\%), ++ more than sparse (15-30\%), +++ abundant (50-60\%), ++++ very abundant (70\% and more). An empty case means that the item was not observed

$n$ number of specimens examined 
Fig. 4 Munidopsis andamanica from Vanuatu. a Semi-thin cross-section of the anterior hindgut. Wood fragments (arrowheads) in the contents are blue-stained, organic matter is purple-stained, and the mineral fraction appears as dark particles (arrows). b Detail of a fragment of wood (xylem tissue), with empty cell lumens and thick secondary walls. At the periphery, the cell walls are degraded by microorganisms and the cells are filled with exogenous material. c, d Semi-thin section of the posterior hindgut with (d) fungal mycelium filaments (dotted arrow) located between the gut content and the cuticle. e Ultrathin section of a wood fragment, with peripheral cells filled with exogenous organic material and minerals (thin arrows). $\mathbf{f}$ Traces $(t)$ left by tunnelling bacteria having perforated secondary walls $(w)$ of a wood fragment in the gut. Cont gut content, $\mathrm{Cut}$ cuticle lining, Epi epiderm, $t$ traces of bacteria, $w$ secondary walls of wood fragments, arrowhead wood fragment, arrow minerals, dotted arrow fungal mycelia

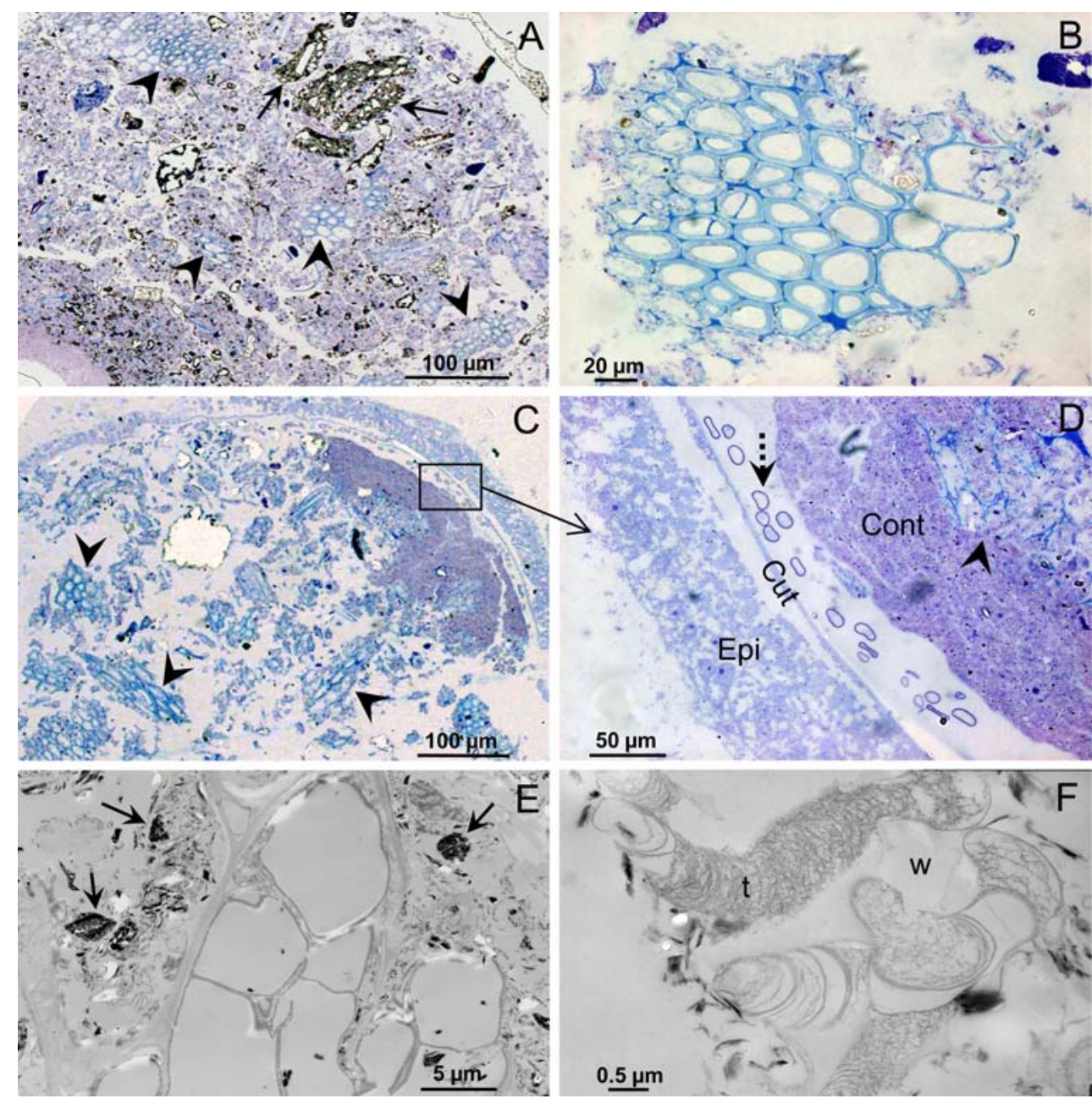

leaves and wood. The difference with the other specimens (from New Caledonia, Indonesia, and Philippines) is observed in the lower proportion of vegetal cells and in the presence of other organic fragments, as branching filaments of algae (50-100- $\mu \mathrm{m}$ width; Fig. 6a) in the gut of the Indonesian specimen, or fungi filaments $(5-40-\mu \mathrm{m}$ width; Fig. 6b) in the gut of the Fijian specimen. Both algae and fungi are found in great amounts in the gut of the specimen from New Caledonia. In contrast to terrestrial plants fragments, algae filaments do not show cells with strong broken walls, angular disposition and open punctuations between them. They rather appear as ribbon-like structures with several cells abreast in width, thin intercellular walls that are often folded and a smooth, external surface giving a hint of the cells beneath. The fungus hyphae appear as single files of cells and exhibit a thick, wrinkled surface such as resident gut fungi (see below). Other organic fragments in the gut of specimens from Solomon Islands, New Caledonia and Philippines are identified as gorgonin (Fig. 6c), i.e. organic matrix of the corneous skeleton in gorgonians, whose elemental microanalysis shows a major peak of sulfur (e.g. see Block and Bolling 1938). These gorgonin frag- ments are sometimes associated with mineral debris of gorgonian skeleton (Ca-phosphate, see below). The gut content of all specimens, recovered or not with wood falls, includes rod-shaped bacteria $(1 \mu \mathrm{m} \times 0.25 \mu \mathrm{m})$, either isolated or compacted into pellets that can be very large (up to $180 \mu \mathrm{m}$ in diameter; Fig. 5d, e). The DAPI-staining of the gut cross-sections of the Solomon Islands' specimen gives evidence of a lot of bacterial rods inside the digestive content (Fig. 7). Finally, in all individuals, SEM (Fig. 5f) as well as LM (Fig. 4a) and TEM (Fig. 5g) reveal coarse, torn organic matter between the larger, recognizable, organic and mineral fragments. This matter is often mixed with scaly clay particles $(3-5 \mu \mathrm{m})$ described below. Among the unidentified organic material in the gut content of Vanuatu specimens, recognizable constituents are membrane remains or vesicles, bacterial cell ghosts, small debris of plant cell walls, and secretions left in wood cell walls by tunneling bacteria (compare Figs. 4f, 5g). Thus, the organic fraction in the gut content of $M$. andamanica appears to consist mostly of highly degraded vegetal debris (terrestrial plants, algae) and other refractory materials, as gorgonin fragments and mycelium filaments and also in a large 
Fig. 5 Munidopsis andamanica from Vanuatu. a Bacteria and $\mathbf{b}$ fungi at the surface of wood fragments in the gut. c Shaving-shaped wood fragment observed by SEM. d, e Pellet of rod-shaped bacteria. f Organic matter mixed with clay particles (arrows), and $\mathrm{X}$-ray spectrum of clay particles showing $\mathrm{Al}, \mathrm{Si}, \mathrm{Ca}$, and $\mathrm{Fe}$ major peaks. g Organic remains in the gut content as viewed by TEM. $m$ membrane remains or bacterial ghost, $t$ traces of tunnelling bacteria, arrows clay particles
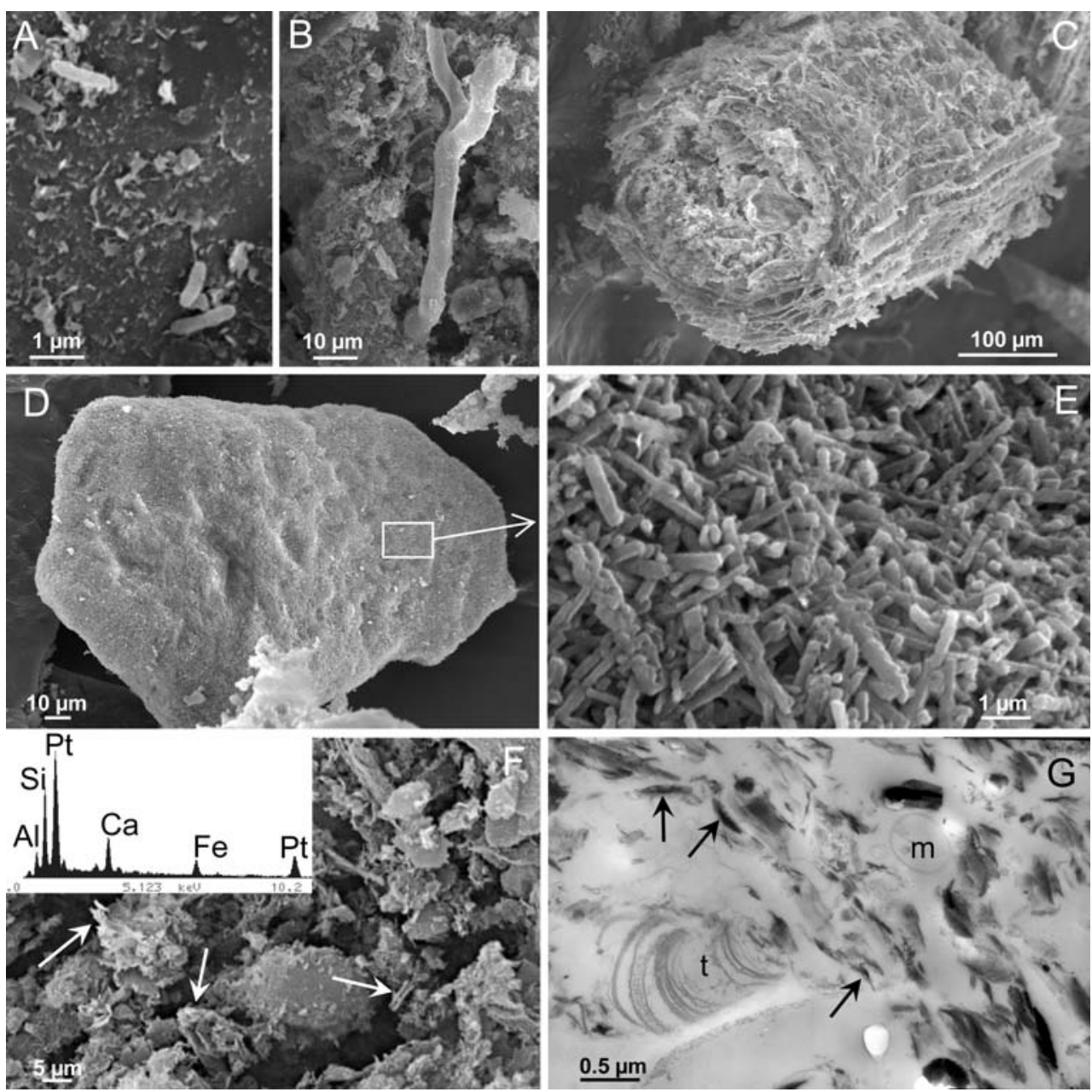

Fig. 6 Munidopsis andamanica gut contents. a Branching algae and $\mathbf{b}$ fungi filaments in the specimen from New Caledonia. c Gorgonin in the specimen from Fiji Islands, d mineralized Ca-phosphate skeleton of a gorgonian coral in the specimen from the Philippines
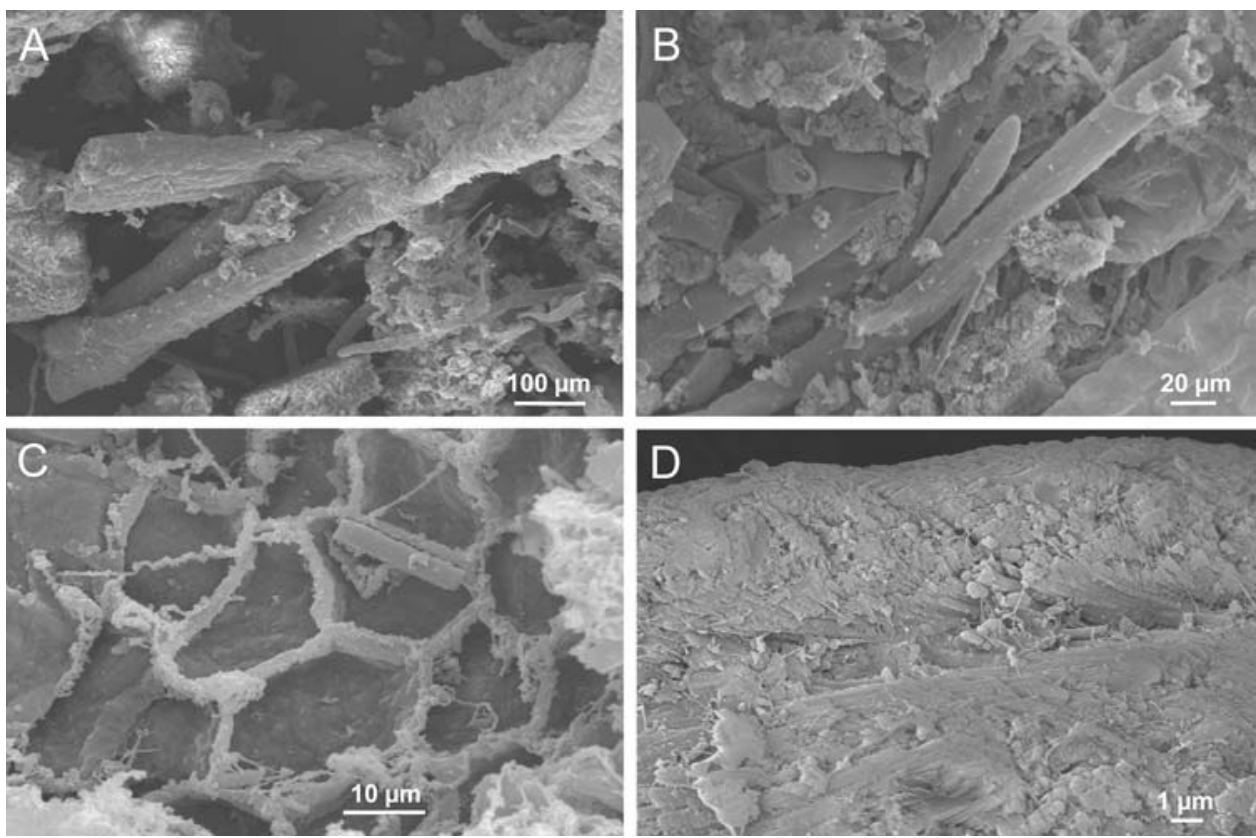


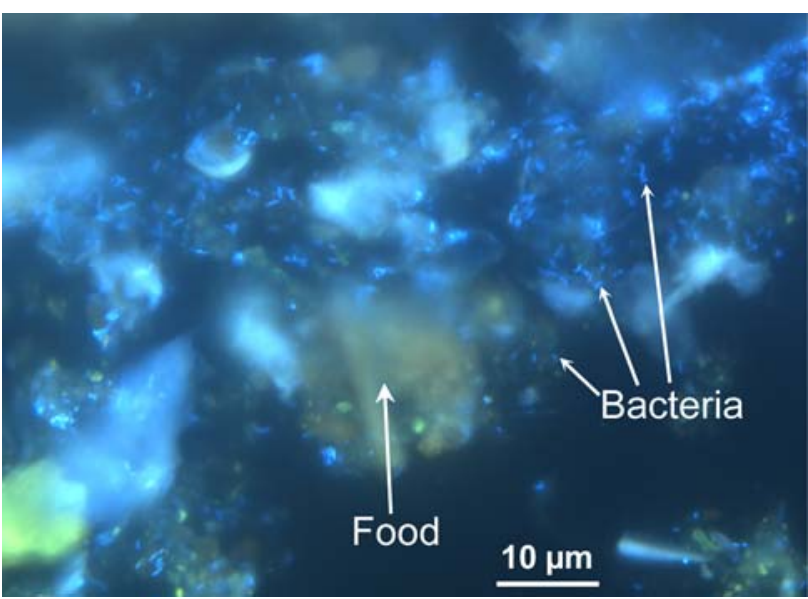

Fig. 7 Munidopsis andamanica from Solomon Islands. DAPI-staining of the bacteria fluorescing in blue inside the gut content. Their shape of small rods enables us to differentiate them from some elements that have a natural auto-fluorescence like the minerals or the lignin of the wood fragments

proportion of bacteria either from surface biofilms or from the inside of decaying substrates. No cuticle fragments are seen, however, suggesting that $M$. andamanica does not feed on crustacean preys or cadavers. Animal tissue remains cannot be excluded, but if present, they must come from animals other than crustaceans.

In all specimens, the minerals and mineralized structures of the gut content consist of clay particles, intact or broken perforated globular foraminifer tests, straight and spiny spicules as well as other mineral fragments (Table 1). The clay particles appear scaly by SEM, as darkly stained particles by LM (Fig. 4a), and as stacks of parallel electron-dense sheets by TEM (Fig. 5g). Their nature was confirmed by X-ray spectra showing major $\mathrm{Al}\left(\mathrm{K}_{\alpha} 1.48 \mathrm{keV}\right), \mathrm{Si}\left(\mathrm{K}_{\alpha} 1.73 \mathrm{keV}\right)$, $\mathrm{Ca}$, and $\mathrm{Fe}\left(\mathrm{K}_{\alpha} 6.4 \mathrm{keV}\right)$ peaks (Fig. 5f). The calcareous composition of foraminifer tests was confirmed by spectra dominated by Ca peaks $\left(\mathrm{K}_{\alpha}: 3.69 \mathrm{keV}, \mathrm{K}_{\beta}: 4.01 \mathrm{keV}\right)$. The microanalysis revealed the siliceous nature of some spicules, which might thus be sponge spines. In the specimen from Fiji, structures looking like mineral fragments of gorgonian coral skeletons are identified on the basis of the crossed disposition of the crystals (Fig. 6d), and their X-ray spectra dominated by significant $\mathrm{Ca}$ et $\mathrm{P}\left(\mathrm{K}_{\alpha}: 2.013 \mathrm{keV}\right)$ peaks. Calcium phosphate particles found in the bolus of the specimens from Fiji Islands, Solomon Islands, and Indonesia could also originate from gorgonian skeletons. Finally, the spectra obtained with wood fragments displayed minor $\mathrm{Si}$ and Ca peaks, compatible with the mineral content of wood.

\section{Gut microorganisms}

No microflora was found on the foregut lining of $M$. andamanica, but microbial colonization (i.e. bacteria and fungal mycelia) was obvious in the hindgut of all specimens.
The pictures show that in all specimens from wood falls of Vanuatu, rod-shaped bacteria $(1.5 \mu \mathrm{m} \times 0.25 \mu \mathrm{m})$ are distributed all along the hindgut (Fig. 8a). Often attached to the cuticle spines of the villous plates, these bacteria are mostly found at higher density in the depressions between plates (Fig. 8b, c). In the median dorsal zone of the hindgut, they are generally stuck together, whereas they are more separated from each other in the ventral zone. In some places, they are glued in mucous secretions, probably of bacterial origin (Fig. 8d). Bacteria are also observed on ultra-thin sections (Fig. 8e). Although ill-defined, the cell envelope displays two membranes as classically found in Gram-negative bacteria (e.g. Costerton et al. 1974). Table 1 shows that such resident rod-shaped bacteria are found in the hindgut of the specimens from others locations, except in the Indonesian specimen. Yet, it was noticed that the bacterial colonization was less extended and patchier in the individuals from New Caledonia, Fiji Islands, Indonesia, and Philippines than in the specimens from wood falls of Vanuatu and Solomon Islands.

In all specimens from wood falls of Vanuatu, except the one from the SantoBOA cruise, large filaments resembling fungal hyphae in shape and size $( \pm 2.3 \mathrm{~mm} \times 8 \mu \mathrm{m})$ are observed in the posterior hindgut. Their surface is delicately and longitudinally wrinkled. They cover an average of $20 \%$ of the hindgut surface, according to measurements taken on SEM objects. SEM (Fig. 9a, b) and LM (Fig. 4d) pictures show that these filaments surround the gut content, like a cylindrical cover between the cuticle and the ingested food. Some of the hyphae clearly appear to be attached to the hindgut cuticle (Fig. 9c, d), with a pot-bellied base (12- $\mu \mathrm{m}$ width) upstream and a filament extending toward the anus. Others are attached downstream, with the filament extending up the digestive tract. Their eukaryotic fungal nature is confirmed by the observation of cell nuclei and thick cell walls by TEM (Fig. 8e). In their distal part, the filaments exhibit round-shaped or ovoid fructifications appearing to vary in number from 7 to 35 "cells" at least (Fig. 9f). Rod-shaped bacteria are found at some locations on the stems of the fungal filaments. Fungi attached to the hindgut lining are also found in specimens from New Caledonia, Indonesia, and Philippines, but neither in those from Solomon nor in those from Fiji Islands (Table 1). The hyphae roughly correspond to the above description. The only differences consist in the length of the filaments, that are much shorter (from 10 to $40 \mu \mathrm{m}$ ) in the specimen from New Caledonia, and in attach of the filament to the cuticle surface. Instead of a pot-bellied base the filaments have a cylindrical, narrow foot of $5 \mu \mathrm{m}$ in length in the specimens from New Caledonia and Indonesia. Only the resident fungi found in the specimens from Vanuatu exhibits distal fructifications. Fungal colonizations were also less expanded in individuals from New Caledonia and Philippines. 

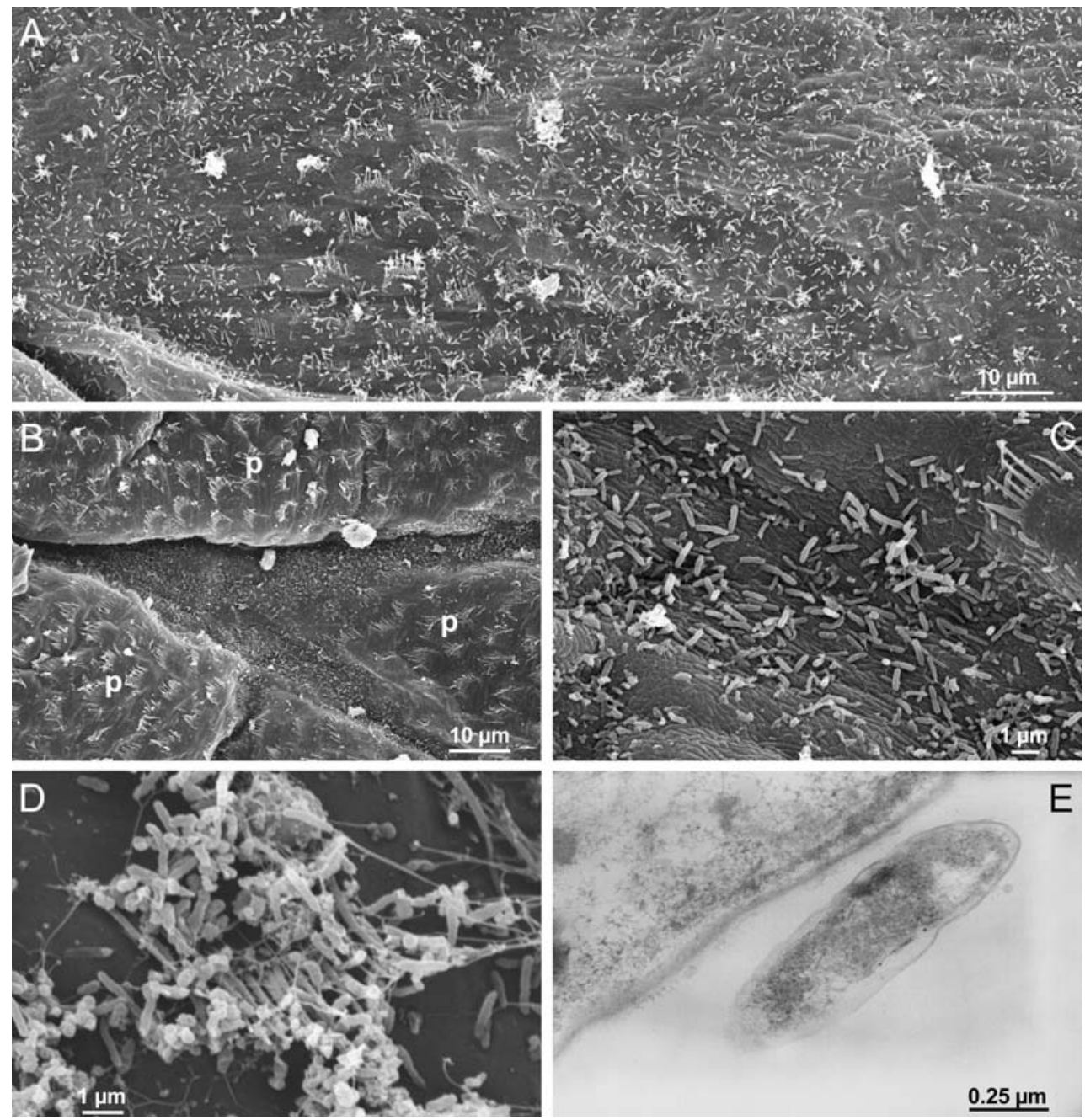

Fig. 8 Munidopsis andamanica from Vanuatu hindgut. a Rod-shaped bacteria $(1.5 \times 0.25 \mu \mathrm{m})$ widely distributed over the hindgut lining, $\mathbf{b}$, c higher density of bacteria in the grooves between the villous plates

$(p), \mathbf{d}$ bacteria attached to the cuticular spines and glued in mucous secretions, and e TEM view of a bacterium showing its Gram-negative cell envelope. $p$ villous plates

\section{Discussion}

In the absence of any possible in situ observations on $M$. andamanica, the morphological approach has been most helpful in supplying information on its feeding ecology. While some morphological features may be constant within families, it has been shown that the mouthparts and digestive tract morphology can vary according to the type of mastication (Powell 1974; Kunze and Anderson 1979; Icely and Nott 1984; Ngoc-Ho 1984; Felgenhauer and Abele 1985; Skilleter and Anderson 1986; Wolfe and Felgenhauer 1991; Pinn et al. 1999; Ceccaldi 2006). We have also been able to relate the diet of the host to the presence of microbial symbionts of several types that can play a role in the digestion, especially in detritivorous and herbivorous species (Harris 1993; Pinn et al. 1999).
On what does it feed?

Our results clearly show that $M$. andamanica associated to wood falls (from Vanuatu and Solomon Islands) is at least partially xylophagous. Yet, observations, particularly of others specimens (from New Caledonia, Philippines, Indonesia, and Fiji Islands), suggest that $M$. andamanica is not exclusively xylophagous but rather a specialist of refractory substrates. Moreover, bacteria associated to the ingested substrates (i.e. the biofilm) should highly contribute to its diet.

Munidopsis andamanica associated to sunken woods feeds directly on them, as attested by the quantity of wood fragments found in its gut contents. Other indications that the squat lobster feeds on the deposit substrate are the presence of clay spangles and the shaving-like wood fragments in the gut, suggesting that $M$. andamanica grazes silty 

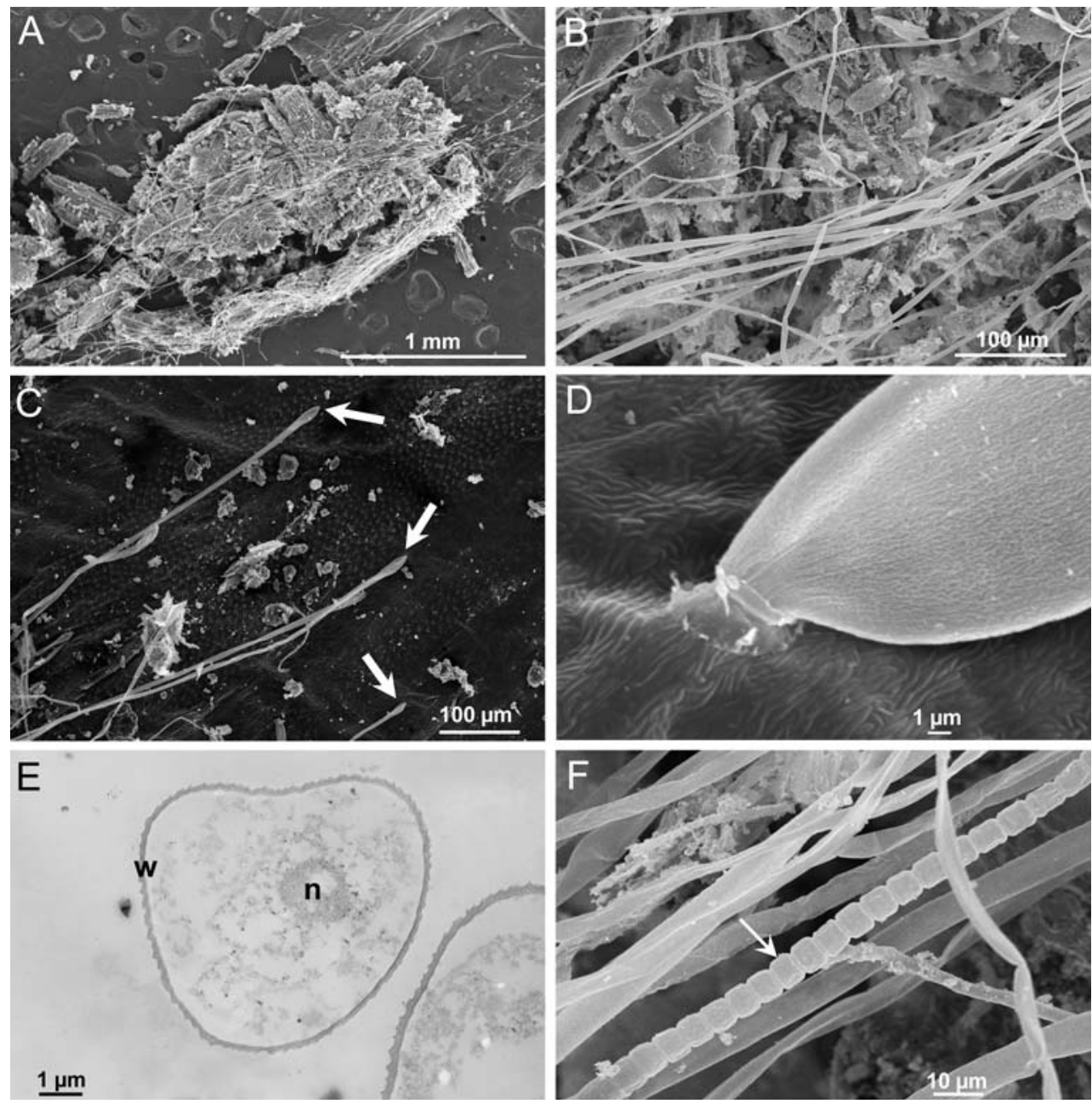

Fig. 9 Munidopsis andamanica from Vanuatu posterior hindgut. a, b Fungal mycelia $( \pm 2.3 \mathrm{~mm} \times 8 \mu \mathrm{m})$ surrounding the gut content, c, $\mathbf{d}$ fungal mycelia attached (large arrows, $\mathbf{c}$ ) to the cuticle lining, e cross-section of a fungal filament showing the cell nucleus $(n)$ and

wall ( $w)$, $\mathbf{f}$ vegetative fructifications of the fungal hyphae (thin arrow). $n$ cell nucleus of fungal mycelium, $w$ wall of fungal mycelium, large arrow base of the fungal mycelia, thin arrow fructifications of fungal mycelium

sunken wood. The clay spangles, as the calcareous and siliceous fragments from various organisms (i.e. tests of protists, mineralized gorgonian skeletons, sponge spicules), certainly have a sedimentary origin. On the other hand, organic matter other than wood, of unknown origin, constitutes a considerable proportion of the gut contents, and thus seems to be an important food source for $M$. andamanica on sunken woods. The large bacterial pellets found in the gut of some specimens suggest that $M$. andamanica may be able to feed on the biofilm covering the substrate. Although unrecognizable with the exception of traces of tunneling bacteria and some membrane vesicles or bacteria ghosts, this organic matter might be degraded microorganisms and/ or highly decomposed wood components. The comparison between specimens from wood falls and those from other substrates (not reported) strongly suggest that the species $M$. andamanica is rather specialized in eating refractory substrates, including wood, algae, fungi, and the corneous

skeletons of gorgonian corals. It seems, however, to have a clear preference for terrestrial vegetal remains. Indeed, at least one of these refractory substrates occurs in all the specimens (Table 1) and can reach high quantities, especially when it consists of wood. Even if soft animals' tissues cannot be excluded from the diet, a predatory behavior should be ruled out. Indeed, the morphology of the spindly claws strongly reduces this hypothesis. Instead, the scavenging of worms or mollusks from sunken wood, which represent a large part of the macrofauna associated to wood falls ecosystems (Samadi et al. 2005) remains possible, but is not defended by any evidence. A much more probable source of nutrients other than wood would be bacteria ingested with the substrate. Even if there is no direct evidence of bacterial digestion by $M$. andamanica, many bacteria were found in the gut contents, especially with the DAPI-staining and in SEM showing bacteria clustered into large pellets. Traces of bacteria viewed in TEM, notably 
inside the vegetal cell walls, support the view that bacteria were degrading the substrate and most probably alive before being ingested. The squat lobster ingesting deeply degraded wood could first benefit from the action of freeliving wood bacteria that release degradation products and nutritive compounds. The presence of numerous bacterial ghosts on the TEM sections suggests that a great proportion of the free-living wood bacteria die during the transit. This does not exclude that some of them survive and develop into a transitional microflora in the digestive tract and could provide cellulose-degrading enzymes as it is proposed for the resident microflora (see below).

\section{How does it feed?}

The claws, mouthparts, and foregut morphology of M. andamanica are in good agreement with the diet of the species as determined by analysis of the gut contents. The feeding appendages appear similar to those of detritivorous decapods, while the gastric mill is suggestive of deposit-feeding. On these bases, a processing sequence for food items, especially wood pieces, is proposed.

\section{Feeding appendages morphology}

The spindly chelipeds of $M$. andamanica are not those of a predator. The use of the chelipeds for feeding is often reported for both crabs and galatheid squat lobsters (e.g. Munida sarsi, according to Hudson and Wigham 2003). It was also observed directly on board during the SalomonBOA3 cruise, with freshly collected live galatheid specimens other than $M$. andamanica (C. Hoyoux, personal observation). The fingers of $M$. andamanica, forming a spoon, not gaping and with prehensile edges crenulated, might hold a piece of decayed wood by clasping (e.g. a splinter at the surface of a log), tear the piece off by crushing its teeth fingers against each other, and then finally bring the freshly cut fragment to the third maxillipeds, using the spoon-shaped depression to retain it. Bacteria found in the gut contents could be highly likely be ingested with the wood fragment, but this depression could also scrape the biofilm covering the substrate producing the pellets of bacteria. Among the 224 species of Munidopsis spp. discovered up to now (see Baba et al. 2008), at least 49 species have this type of chelipeds. Interestingly, although the diet of very few of them was described, it appears that species feeding at least partially on bacteria have often this spoon-shaped structure (e.g. M. alvisca, M. subsquamosa, M. crassa, M.aries) in contrast to some others that would be predators or scavengers (e.g. M. acutispina, M. marionis, M. serricornis). Such spoon-shaped chelipeds are also reported in herbivorous crab species (Wolcott and O'Connor 1992) for collecting plants (Coen 1987) and in two specimens of Munidopsis spp. that had plant fragments in their foregut (Gore 1983).

The mouthparts of $M$. andamanica exhibit features suggesting that they are adapted to manipulating large food items. It is commonly accepted that teeth-like structures, i.e. a well-developed crista dentata on the third maxillipeds, spiny first maxillae, and well-developed mandibles, enable clasping as well as shredding of larger food items (Caine 1974; Kunze and Anderson 1979; Stamhuis et al. 1998; Martin et al. 1998; Garm and Høeg 2001; Salindeho and Johnston 2003). Although these morphologies are often reported to a carnivorous feeding (e.g. Kunze and Anderson 1979), these are also found in deposit-feeders (Salindeho and Johnston 2003; Garm and Høeg 2001; Nickell and Atkinson 1995; Stamhuis et al. 1998). Yet, Nickell et al. (1998) and Coelho and Rodrigues (2001) consider that the morphology of the crista dentata is linked to phylogeny rather than to the type of feeding, but they do not exclude the possibility that this structure might be used in situ to catch food, since the specimens they studied were fed in captivity. We can thus suggest that these features may simply indicate an aptitude to process large food items, for carnivorous as well as for detritivorous species. In M. andamanica from wood falls, the crista dentata could be used in feeding to hold wood pieces firmly and to push them toward the mandibles. Furthermore, the symmetry of the mandibles of $M$. andamanica is not typical of a carnivorous species, as this feeding type often implies asymmetrical mandibles (Kunze and Anderson 1979; Skilleter and Anderson 1986; Salindeho and Johnston 2003).

Construing the function of the setae covering the mouthparts is quite difficult. Some authors have tried to link function to setal morphology, but sometimes similar morphologies fulfill several possible functions (Factor 1978; Schembri 1982; Felgenhauer and Abele 1985; Crain 1999; Stamhuis et al. 1998; Coelho and Rodrigues 2001; Garm and Høeg 2001). The literature suggests that serrate setae can play a role in chemosensitivity, cleaning, or food adhesion; cuspidate setae can play a role in grasping food; plumose setae are often involved in creating water currents important in respiration or suspension-feeding; and pappose setae do not participate in food handling but usually create setal barriers. $M$. andamanica has very few plumose setae on its mouthparts, confirming that it is clearly not a suspensionfeeder. The majority of setae on the third maxillipeds are serrate chemoreceptive setae and pappose setae that can retain fine food particles stuck in the setules. The cuspidate setae on the basipodite of the first maxillae could help to grasp food.

\section{Gastric mill morphology}

The gastric mill of $M$. andamanica exhibits morphological characteristics generally found in deposit-feeders (Kunze 
and Anderson 1979; Pinn et al. 1999; Salindeho and Johnston 2003): few setae, a simple strong dorsal tooth, and large, oval-shaped lateral teeth with deep transversal ridges, few flexible spines, and a large anterior denticle. This is clearly different from suspension-feeders, the gastric mill of which usually has many setae, a complex dorsal tooth, and rhomboidal lateral teeth with many stout spines having a comb-like appearance (Pinn et al. 1999). In M. andamanica, the simple, strongly calcified, and robust teeth might be adapted to processing hard substrates and specialized for crushing and grinding wood fragments. Interestingly, similar morphological features of the gastric teeth are found in herbivorous crabs, where they are used to crush fibrous plant materials (Coen 1987; Warner 1977; Giddins et al. 1986). This is especially true for the mangrove crab Neosarmatium smithi, which feeds on mangrove litter that has decayed for several weeks. This crab has robust, smooth gastric teeth with deep grooves (i.e. molar-shaped teeth). Large spines encircling the accessory lateral tooth are also found in $M$. andamanica in addition to lateral teeth. Together, these spines and teeth might, like the lateral teeth of deposit-feeders, help to maintain food particles such as wood shavings, while the dorsal tooth would grind the food particles like a pestle on a mortar.

Munidopsis andamanica thus possesses the feeding appendages and gastric mill of a detritivorous depositfeeder that seems fairly well adapted to feeding on wood. $\mathrm{Up}$ to the foregut, the treatment sequence of food, especially wood pieces, in $M$. andamanica might be described in three steps as follows : (1) use of the chelipeds to tear off a partially degraded wood fragment and bring it between the crista dentata of the third maxillipeds, (2) production of shavings from the wood fragment maintained by the maxillipeds and spiny maxillae, by grating with the incisor cutting edge of the mandibles, and (3) crushing of the wood shavings between the lateral and dorsal teeth of the gastric mill. This scenario suggests that $M$. andamanica would not directly bore the wood surface and does not form a part of the first colonizers of the sunken wood; this agrees with the behavior of some species of the genus (e.g. M. crassa and another Munidopsis sp.) which come later in the colonization of a bait (e.g. thuna or seal cadaver) compared to other scavengers as fishes and amphipods (Janßen et al. 2000; Kemp et al. 2006).

Role of the resident gut microorganisms

It is generally recognized that the gut microflora of marine detritivores provide the host with a complementary enzymatic arsenal for the degradation of refractory ingested organic substrates (Dempsey and Kitting 1987; Plante et al. 1990; Erasmus et al. 1997). Harris (1993) further suggests that the degree and type of colonization of the decapod digestive tract is related to the diet. Thus, carnivorous species show little evidence of bacterial colonization in the gut, while the hindgut of detritivorous decapods is extensively colonized. In contrast to the symbionts harbored by mollusk and annelid tissues, which are generally intracellular (i.e. endosymbionts), crustacean symbionts are often extracellular (i.e. ectosymbionts) and located on the cuticle lining of the hindgut as in the digestive symbioses described in detritivorous isopods (Zimmer and Bartholmé 2003; Lindquist et al. 2005), thalassinid shrimps (Pinn et al. 1999; Lau et al. 2002; Harris 1993), prawns (Zbinden and Cambon-Bonavita 2003; Oxley et al. 2002), and crayfishes (Growns and Richardson 1988) which feed on leafs litter (Guan and Wiles 1998; Reynolds and O'Keeffe 2005).

The present results reveal a considerable microflora of resident bacteria and/or fungi in all specimens examined. Moreover, it is likely that some bacteria from the gut contents form a living transitional microflora.

Based on both the literature (Smith and Douglas 1987; Margulis et al. 1990; Douglas 1994; Zook 1998; Bricage 1998, 2000; Werner et al. 2002) and our own observations of the bacteria covering the hindgut lining of M. andamanica, we here propose four morphological criteria that could define a resident, possibly symbiotic association: (1) the association occurs in all examined specimens, (2) the microorganisms are consistently located on the gut lining, (3) the supporting tissues appear healthy, and (4) the diet of the host suggests a requirement for digestive symbionts. The xylophagous, detritivorous diet of $M$. andamanica associated to wood falls strongly suggests a need for this symbiotic digestive microflora. The colonization less extended or patchier in the case of specimens from substrates not reported would be linked either to their molt stage or to their diet less rich in vegetal fragments. For example, in the specimen from Indonesia, contrarily to the occurrence of resident fungi, no bacterial colonization was found (Table 1). During transit through the hindgut, digestion of wood might be assisted by the activity of resident bacteria, surviving transitory bacteria, or both. The proliferation and activity of these bacteria could enrich the feces in nutrients. As suggested for mangrove grapsid crabs (Webster and Benfield 1986), M. andamanica should both accelerate wood decay by tearing off pieces and enrich the medium in nutrients by producing feces containing wood fragments partially degraded by the microorganisms of its digestive tract. The role of such detritivores is recognized as very important in the biodeterioration of deep-sea organic substrates (Schwarz et al. 1976; Palacios et al. 2006).

In $M$. andamanica, interestingly, the bacteria are not attached only to the microspines of the hindgut lining but appear massed in the folds between the spiny villous plates. This suggests that the cuticular spines might not really be 
necessary for bacterial attachment as proposed by Brecko and Strus (1992) and Pinn et al. (1999). They might, rather, play a mechanical role, facilitating the transit of the fecal pellets through the hindgut (Pillai 1960; Dall 1967; Bignell 1984; Felgenhauer 1992). According to our observations on $M$. andamanica, attachment of the bacteria should be favored by the nanorelief of the cuticle surface, which provides small depressions precisely in the size range of the observed rod-shaped bacteria. This contributes to the debate on the role of the cuticle microdentition.

The presence of resident bacteria in the hindgut of $M$. andamanica further suggests that most of the digestion might occur in the hindgut, like in the terrestrial isopod Porcellio scaber, which feeds on leaf litter and harbors cellulolytic bacterial endosymbionts in its digestive gland (Zimmer and Topp 1998). Two ways could be considered for M. andamanica to gain nutrients: they are either obtained through the very thin cuticle of the hindgut or by the ingestion of feces. The part of nutrients that are not assimilated then would be definitively lost and would enrich the environment. Moreover, this important role of the hindgut is likely related to the reduced size of the midgut which, although not observed here because of its tendency to break off, appears very short in $M$. andamanica.

The fungal mycelia detected in $M$. andamanica meet only three of the four criteria of a symbiotic association. They are frequently found and always located in the posterior hindgut. They are oriented and anchored to the cuticle lining. They reproduce outside the gut contents and they do not seem to be parasitic, given the apparent good health of the tissue. Their anchorage to the cuticle suggests that they are not environmental fungi ingested with wood fragments. Morphologically, the fungal microflora of $M$. andamanica also appears very different from the fungi found in the sunken wood itself (Dupont et al. 2005). The vegetative fructification of the hyphae in Vanuatu specimens and their location at the end of the hindgut might be due to the high nutrient content of the posterior feces, enriched by the upstream bacterial proliferation. Yet their absence in some specimens might indicate that these fungi are not obligate symbionts. Although resident fungi are generally considered pathogens in marine invertebrates (López Lastra 1990; Lichtwardt 1996; Alencar et al. 2003), complex digestive symbioses have been described between cellulase-producing fungi and arthropods (Martin 1992; Kimura et al. 2002). An example of digestive symbiosis is found in the squat lobster Munidopsis subsquamosa from hydrothermal vents, which hosts a trichomycete in the foregut. It thus seems likely that the hindgut fungi of $M$. andamanica continue the digestion of wood, perhaps by degrading lignin which should be present in the xylem of ingested wood fragments, and is known to be attacked by fungi (e.g. Hammel 1997). Fungal microorganisms might considerably assist digestion of the ligneous wood, plant and/or algae that $M$. andamanica ingests.

Herbivorous specialist or generalist scavenger?

Squat lobsters are generally thought to be scavengers, and few studies have focused on the diet of species of the genus Munidopsis. Even rare, these studies give nevertheless evidence of differences of diet within the genus (Van Dover and Lichtwardt 1986; Chevaldonné and Olu 1996; Janßen et al. 2000; Escobar-Briones et al. 2002; Micheli et al. 2002; Phleger et al. 2005; Kemp et al. 2006; Macavoy et al. $2008 \mathrm{a}, \mathrm{b})$. The diet of $M$. andamanica from deep-sea wood falls, shown here to ingest ligneous wood in large proportion, appears quite original or exceptional. Indeed, various plant materials, e.g. phytoplankton, micro- and macroalgae, foliage, seeds, fruits, and leaf litter have been reported as food sources for different crab species, wood being the exception not listed by Wolcott and O'Connor (1992). However, Gore (1983) examined two specimens belonging to the species $M$. aries and $M$. bermudezi and reported that they had plant fragments in their stomach. Thus, it could be proposed that among the genus Munidopsis, some species are actually scavengers but others, as $M$. andamanica, could have evolved and become specialized in feeding on different hard substrates. The similarity shared by the refractory substrates considered here, i.e. wood, plant debris, algae, and fungi cell walls, as well as hard animal tissues as corneous gorgonians skeletons and vertebrate bones, is a fibrous texture and macromolecules stabilized by hardy breakable covalent links. Generally, animals do not dispose of the endogenous enzymes to degrade such organic substrates. Feeding on them should thus be considered as a specialization different from usual scavenging that does not require any peculiar adaptation when restricted to the feeding on soft tissues from dead animals. As showed by Kiel et al. (2008), some species (e.g. Xylophaga) appears to be specialized in a wood-based diet at least since the late Cretaceous.

Despite of the negative aspects and constraints in using plants as food instead of animal tissues, herbivory is a common phenomenon in many decapod crustaceans, especially crabs, in both aquatic and terrestrial habitats (Wolcott and O'Connor 1992) and even in species considered carnivorous (Warner 1977). Using plants as a food source does have many negative aspects and constraints, such as: the presence of refractory components such as lignin, cellulose, tannins, and phenolics that are difficult to digest (Mattson 1980); calcifications causing excessive wear on the chelae, mandibles, and teeth of the gastric mill (Coen 1987); given the high $\mathrm{C} / \mathrm{N}$ ratio of plants, the $30 \%$ lower nitrogen content of a plant-based versus an animal-based diet (Wolcott and Wolcott 1984) and lower levels of essential amino 
acids, vitamins, sterols, and polyunsaturated fatty acids as compared to animal tissue (Phillips 1984). Thus, planteating decapods are generally not exclusively herbivorous, benefiting from other food sources or using various means to offset the unfavorably high $\mathrm{C} / \mathrm{N}$ ratio. The mangrove crab $N$. meinerti, which eats leaf litter, is proposed to derive a significant part of its diet by foraging sediment detritus, a richer source of nitrogen (Skov and Hartnoll 2002). Furthermore, these crabs fragment leaves during feeding (Malley 1978), with subsequent acceleration of microbial decay (Webster and Benfield 1986) and a decrease in the $\mathrm{C} / \mathrm{N}$ ratio (Cundell et al. 1979).

Our results on $M$. andamanica showed that this species does not break with the rule. Even if almost all the specimens have vegetal debris in their gut contents, they also manifestly feed on other organic matters. The results of our examination of $M$. andamanica gut contents strongly suggest that the $\mathrm{C} / \mathrm{N}$-ratio-reducing secondary food source of $M$. andamanica is the bacteria found in high quantities in all gut contents, likely originating from the biofilm growing at the surface of decayed wood or other hard substrates. The large amount of fungi found in the bolus of two specimens (New Caledonia and Fiji) should play the same role as ingested bacteria. Such an alternative food is indeed required by most wood-eating species, because the xylem consists solely of thick lignified cell walls and is devoid of even remnants of cytoplasm. Thus, the biofilm may be an important supply of molecules and elements lacking in wood. It is noteworthy in this context that $M$. andamanica does not bore into intact sunken wood, but rather ingests partially degraded wood fragments that it tears off or grazes at different places. The periphery of these fragments generally shows alterations, such as perforations by tunneling bacteria, which occurred in the environment prior to ingestion of the fragments.

In conclusion, $M$. andamanica is predominantly a detritivorous deposit-feeder and, as such, has robust mouthparts and a robust gastric mill. By its regular distribution with a number of individuals on wood falls, by the presence of a high proportion of wood or plant debris in the gut of numerous specimens, by the morphology of its appendages and gastric mill as well as by the regular presence of two kinds of digestive symbionts (bacteria and fungi), $M$. andamanica has to be regarded as a specialist adapted to feed preferentially on terrestrial vegetal remains but also by extension on other hard refractory substrates of animal origin. Although the specimens associated with wood appear to feed mainly on the wood itself, ingesting large quantities of xylem tissues, an important other food source should be the bacteria and the fungi grazed from biofilms. Comparing the feeding habits of M. andamanica with the ones of other Munidopsis species let us think that this species and perhaps some of its congeners have evolved differently from others among the genus. On the other hand, M. andamanica has developed lasting associations with fungal and bacterial resident gut microorganisms, which most probably assist digestion of the refractory components, especially in the case of a woodbased diet.

Munidopsis andamanica is likely to be an important actor in the food chains of deep-sea wood falls, through its ability to mechanically degrade wood and to produce, as is usual for herbivores, feces enriched in nutrients and organic nitrogen (Wafar et al. 1997; Skov and Hartnoll 2002). This conclusion breaks with the widespread idea that squat lobsters are generalist scavengers.

Acknowledgments The authors thank the chief scientists of the BOA1 and SantoBOA cruises, S. Samadi and B. Richer de Forges, respectively, and also the captains and crews. SantoBOA was included in the Biodiversity expedition Santo MNHN/PNI/IRD (Co-PI: P. Bouchet, O. Pascal and H. Le Guyader) that was supported by grants from the Total Foundation. The authors also gratefully acknowledge the excellent technical assistance of N. Decloux with transmission and scanning electron microscopy. Thanks are also due to E. Macpherson for the taxonomic determination of the specimens. Thanks also go to the reviewers for providing constructive comments on the manuscript. This work is included in the GDRE-DIWOOD research program ("Diversity, Establishment, and Function of Organisms Associated with Marine Wood Falls") directed by F. Gaill and was supported by the Belgian Fund for Joint Basic Research (F.R.F.C Belgium, convention no. 2.4594.07.F). Caroline Hoyoux is a $\mathrm{PhD}$ student fellow of the F.R.S-F.N.R.S (National Fund for Scientific Research, Belgium).

\section{References}

Alencar YB, Ríos-Velásquez CM, Lichtwardt RW, Hamada N (2003) Trichomycetes (Zygomycota) in the Digestive Tract of Arthropods in Amazonas, Brazil. Mem Inst Oswaldo Cruz 98(6):799-810

Baba K (1988) Chirostylid and Galatheid crustaceans (Decapoda: Anomura) of the "Albatross" Philippine expedition, 1907-1910. Researches on Crustacea, Special Number 2: v + 203 p

Baba K (2005) Deep-sea Chirostylid and Galatheid crustaceans (Decapoda: Anomura) from the Indo-Pacific, with a list of the species. Galathea report 20, $317 \mathrm{p}$

Baba K, Macpherson E, Poore GC, Ahyong ST, Bermudez A, Cabezas P, Lin C-W, Nizinski M, Rodrigues C, Schnabel K (2008) Catalogue of squat lobsters of the world (Crustacea: Decapoda: Anomura-families Chirostylidae, Galatheidae and Kiwaidae). Zootaxa 1905:1-220

Bayon C (1980) Volatile fatty acids and methane production in relation to anaerobic carbohydrate fermentation in Oryctes nasicornis larvae (Coleoptera: Scarabaeidae). J Insect Physiol. doi:10.1016/ 0022-1910(80)90098-0

Bennett BA, Smith CR, Glaser B, Maybaum HL (1994) Faunal community structure of a chemoautotrophic assemblage on whale bones in the deep northeast Pacific Ocean. Mar Ecol Prog Ser 108:205-223

Bignell D (1984) The arthropod gut as an environment for microorganisms. In: Anderson J, Rayner A, Walton D (eds) Invertebratemicrobial interactions. Cambridge University Press, Cambridge, pp 205-227

Block RJ, Bolling D (1938) The amino acid composition of keratinsthe composition of gorgonin, spongin, turtle scutes, and other keratins. J Biol Chem 127:685-693 
Brecko D, Strus J (1992) The morphology of the hindgut in semi-terrestrial and terrestrial isopods. In: Proceedings of the 1st European Crustacean conference, Paris, pp 17-18

Bricage P (1998) La Survie des Systèmes Vivants. In: Atelier MCX20 Prendre soin de l'homme. Programme Européen Modélisation de la Complexité. MCX, Pau, 19 Oct 1998, 3 p

Bricage P (2000) Systèmes biologiques: Le jeu de la croissance et de la survie. Quelles règles? Quelles décisions? Quels bilans? In: La décision systémique : du biologique au social, AFSCET, Paris, $6 \mathrm{p}$

Caine EA (1974) Feeding of Ovalipes guadulpensis (Saussure) (Decapoda : Brachyura : Portunidae), and morphological adaptations to a burrowing existence. Biol Bull 147:550-559

Cayré P, Richer de Forges B (2002) Faune mystérieuse des océans profonds. La Recherche 355:59-62

Ceccaldi HJ (2006) The digestive tract: anatomy, physiology and biochemistry. In: Forest J, von Vaupel Klein JC (eds) Treatise on zoology-anatomy, taxonomy, biology-the crustacea, vol 2. Brill, Leiden Boston, pp 85-203

Chevaldonné P, Olu K (1996) Occurrence of anomuran crabs (Crustacea: Decapoda) in hydrothermal vent and cold-seep communities: a review. Proc Biol Soc Wash 109(2):286-298

Coelho VR, Rodrigues SA (2001) Trophic behaviour and functional morphology of the feeding appendages of the laomediid shrimp Axianassa australis (Crustacea: Decapoda: Thalassinidea). J Mar Biol Ass UK 81:441-454

Coen LD (1987) Plant-Animal interactions: ecology and functional comparative morphology of plant-grazing decapod (brachyuran) crustaceans. PhD dissertation, University of Maryland

Costerton JW, Ingram JM, Cheng K-J (1974) Structure and function of the cell envelope of gram-negative bacteria. Bact Rev 38(1):87110

Crain JA (1999) Functional morphology of prey ingestion by Placetron wosnessenskii Schalfeew Zoeae (Crustacea: Anomura: Lithodidae). Biol Bull 197:207-218

Cundell AM, Brown MS, Stanford R, Mitchell R (1979) Microbial degradation of Rhizophora mangle leaves immersed in the sea. East Coast Mar Sci 9:281-286

Dall W (1967) The functional anatomy of the digestive tract of a shrimp, Metapeneaus bennettae Racek and Dall (Crustacea: Decapoda: Penaedae). Aust J Zool 15:699-714

Dempsey AC, Kitting CL (1987) Characteristics of bacteria isolated from penaeid shrimp. Crustaceana 52(1):90-94

Distel DL, Roberts SJ (1997) Bacterial endosymbionts in the gills of the deep-sea wood-boring bivalves Xylophaga atlantica and Xylophaga washingtona. Biol Bull 192:253-261

Distel DL, Baco AR, Chuang E, Morrill W, Cavanaugh C, Smith CR (2000) Do mussels take wooden steps to deep-sea vents? Nature. doi: $10.1038 / 35001667$

Dolan MF (2001) Speciation of termite gut protists: the role of bacterial symbionts. Int Microbiol 4:203-208

Douglas AE (1994) Symbiotic interactions. Oxford University Press, Oxford. doi:10.1017/S0025315400047810

Duperron S, Laurent MCZ, Gaill F, Gros O (2008) Sulphur-oxidizing extracellular bacteria in the gills of Mytilidae associated with wood falls. FEMS Microbiol Ecol. doi:10.1111/j.1574-6941. 2008.00438.x

Dupont J, Rousseau F, Zbinden M, Frébourg G, Samadi S, Gaill F (2005) Systematics investigations on a deep sea Ascomycete recovered from wood samples. In: 3rd international symposium on hydrothermal vent and seep biology

Erasmus JH, Cook PA, Coyne VE (1997) The role of bacteria in the digestion of seaweed by the abalone Haliotis midae. Aquaculture. doi:10.1016/S0044-8486(97)00112-9

Escobar-Briones E, Morales P, Cienfuegos E, Gonzáles M (2002) Carbon sources and trophic position of two abyssal species of
Anomura, Munidopsis alvisca (Galatheidae) and Neolithodes diomedeae (Lithodidae). In: Hendrickx ME (ed) Contributions to the study of East Pacific crustaceans. Instituto de Ciencias del Mar y Limnología, UNAM, pp 37-43

Factor JR (1978) Morphology of the mouthparts of larval lobsters, Homarus americanus (Decapoda: Nephropidae), with special emphasis on their setae. Biol Bull. doi:10.2307/1541067

Felgenhauer B (1992) Internal anatomy of the Decapoda: an overview. In: Harrison F, Humes A (eds) Microscopic anatomy of invertebrates. Decapod Crustacea, vol 10. Wiley-Liss, New York, pp 44-75

Felgenhauer BE, Abele LG (1985) Feeding structures of two atypid shrimps, with comments on caridean phylogeny. J Crust Biol 5:397-419

Foglesong MA, Walker DH Jr, Puffer JS, Markovetz AJ (1975) Ultrastructural morphology of some prokaryotic microorganisms associated with the hindgut of cockroaches. J Bacteriol 123(1):336-345

Garm A (2004) Revising the definition of the crustacean seta and setal classification systems based on examinations of the mouthpart setae of seven species of decapods. Zool J Linn Soc. doi:10.1111/ j.1096-3642.2004.00132.x

Garm A, Høeg JT (2001) Function and functional groupings of the complex mouth apparatus of the squat lobsters Munida sarsi Huus and M. tenuimana G.O. Sars (Crustacea: Decapoda). Biol Bull 200:281-297

Giddins RL, Lucas JS, Neilson MJ, Richards GN (1986) Feeding ecology of the mangrove crab Neosarmatium smithi (Crustacea: Decapoda: Sesarmidae). Mar Ecol Prog Ser 33:147-155

Goffredi SK, Paull CK, Fulton-Bennett K, Hurtado LA, Vrijenhoek RC (2004) Unusual benthic fauna associated with a whale fall in Monterey Canyon, California. Deep Sea Res I. doi:10.1016/ j.dsr.2004.05.009

Gore RH (1983) Notes on rare species of Munidopsis (Anomura: Galatheidae) and Ethusina (Brachyura: Dorippidae) collected by the USNS Bartlett in the Venezuela basin, Caribbean Sea. Proc Acad Nat Sci Phila 135:200-217

Gros O, Gaill F (2007) Extracellular bacterial association in gills of "wood mussels". Cah Biol Mar 48(1):103-109

Growns IO, Richardson AMM (1988) Diet and burrowing habits of the freshwater crayfish, Parastacoides tasmanicus tasmanicus Clark (Decapoda : Parastacidae). Mar Freshw Res 39(4):525-534

Guan R-Z, Wiles PR (1998) Feeding ecology of the signal crayfish Pacifastacus leniusculus in a British lowland river. Aquaculture. doi:10.1016/S0044-8486(98)00377-9

Hammel KE (1997) Fungal degradation of lignin. In: Cadisch G, Giller KE (eds) Driven by nature: plant litter quality and decomposition. CAB International, Caen, pp 33-45

Harris JM (1993) The presence, nature, and role of gut microflora in aquatic invertebrates: a synthesis. Microb Ecol. doi:10.1007/ BF00171889

Hashimoto JK, Ohta S, Fujikura K, Miura T (1995) Microdistribution pattern and biogeography of the hydrothermal vent communities of the Minami-Ensei Knoll in the Mid-Okinawa Trough, Western Pacific. Deep Sea Res. doi:10.1016/0967-0637(94)00037-S

Hudson IR, Wigham BD (2003) In situ observations of predatory feeding behaviour of the galatheid squat lobster Munida sarsi (Huus, 1935) using a remotely operated vehicle. J Mar Biol Ass UK 83(3):463-464

Icely JD, Nott JA (1984) On the morphology and fine structure of the alimentary canal of Corophium volutator (Pallas) (Crustacea: Amphipoda). Philos Trans R Soc Lond B. doi:10.1098/rstb. 1984.0081

Janßen F, Treude T, Witte U (2000) Scavenger assemblages under differing trophic conditions: a case study in the deep Arabian Sea. Deep Sea Res II 47:2999-3026 
Kemp KM, Jamieson AJ, Bagley PM, McGrath H, Bailey DM, Collins MA, Priede IG (2006) Consumption of large bathyal food fall, a siw month study in the NE Atlantic. Mar Ecol Prog Ser. doi:10.3354/meps310065

Kiel S, Goedert JL (2006a) A wood-fall association from Late Eocene deep-water sediments of Washington State, USA. Palaios. doi:10.2110/palo.2005.p05-086r

Kiel S, Goedert JL (2006b) Deep-sea food bonanzas: Early Cenozoic whale-fall communities resemble wood-fall rather than seep communities. Proc R Soc B. doi:10.1098/rspb.2006.3620

Kiel S, Amano K, Hikida Y, Jenkins RG (2008) Wood-fall associations from Late Cretaceous deep-water sediments of Hokkaido, Japan. Lethaia. doi:10.1111/j.1502-3931.2008.00105.x

Kimura H, Harada K, Hara K, Tamaki A (2002) Enzymatic approach to fungal association with arthopod guts: a case study for the crustacean host Nihonotrypaea harmandi, and its foregut fungus, Enteromyces callianassae. Mar Ecol. doi:10.1046/j.1439-0485. 2002.02778.x

Kunze J, Anderson T (1979) Functional morphology of the mouthparts and gastric mill in the hermit crabs Clibanarius taeniatus (Milne Edwards), Clibanarius virescens (Krauss), Paguristes squamosus McCulloch and Dardanus setifer (Milne Edwards) (Anomura: Paguridae). Aust J Mar Freshw Res. doi:10.1071/MF9790683

Lau WWY, Jumars PA, Armbrust EV (2002) Genetic diversity of attached bacteria in the hindgut of the deposit-feeding shrimp Neotrypaea (formerly Callianassa) californiensis (Decapoda: Thalassinidae). Microb Ecol 43:455-466

Lichtwardt RW (1996) Trichomycetes and the arthropod gut. In: Howard D, Miller D (eds) The Mycota, animal and human relations. Springer, New York, pp 315-330

Lindquist N, Barber PH, Weisz JB (2005) Episymbiotic microbes as food and defence for marine isopods: unique symbioses in a hostile environment. Proc Biol Sci. doi:10.1098/rspb.2005.3082

López Lastra C (1990) Primera cita de Smittium morbosum var. rioplatensis var. nov. (Trichomycetes: Harpellales) patógeno de cinco especies de mosquitos (Diptera: Culicidae) en la República de Argentina. Re Arg Mic 13:14-18

Lorion J, Duperron S, Gros O, Cruaud C, Samadi S (2009) Several deep-sea mussels and their associated symbionts are able to live both on wood and on whale falls. Proc Biol Sci. doi:10.1098/ rspb.2008.1101

Macavoy SE, Carney RS, Morgan E, Macko SA (2008a) Stable isotope variation among the mussels Bathymodiolus childressi and associated heterotrophic fauna at four cold-seeps communities in the Gulf of Mexico. J Shellfish Res. doi:10.2983/0730-8000(2008)27 [147:SIVATM]2.0.CO;2

Macavoy SE, Morgan E, Carney RS, Macko SA (2008b) Chemoautotrophic production incorporated by heterotrophs in Gulf of Mexico hydrocarbon seeps: an examination of mobile benthic predators and seep residents. J Shellfish Res. doi:10.2983/07308000(2008)27[153:CPIBHI]2.0.CO;2

Macpherson E (2007) Species of the genus Munidopsis Whiteaves, 1784 from the Indian and Pacific Oceans and reestablishment of the genus Galacantha. A Milne-Edwards, 1880 (Crustacea, Decapoda, Galatheidae). Zootaxa 1417:1-135

Macpherson E, Segonzac M (2005) Species of the genus Munidopsis (Crustacea, Decapoda, Galatheidae) from the deep Atlantic Ocean, including cold-seep and hydrothermal vent areas. Zootaxa 1095:1-60

Malley DF (1978) Degradation of mangrove leaf litter by the tropical sesarmid crab Chiromanthes onychophorum. Mar Biol. doi:10.1007/BF00455032

Margulis L, Olendzenski L, Afzelius B (1990) Endospore-forming filamentous bacteria symbiotic in termites: ultrastructure and growth in culture of Arthromitus. Symbiosis 8(2):95-116
Marshall BA (1985) Recent and tertiary deep-sea limpets of the genus Pectinodonta Dall (Mollusca: Gastropoda) from New Zealand and New South Wales. New Zeal J Zool 12:273-282

Marshall BA (1988) Skeneidae, Vitrinellidae and Orbitestellidae (Mollusca: Gastropoda) associated with biogenic substrata from bathyal depths off New Zealand and New South Wales. J Nat Hist 22:949-1004

Martin MM (1992) The evolution of insect-fungus associations: from contact to stable symbiosis. Am Zool. doi:10.1093/icb/32.4.593

Martin JW, Jourharzadeh P, Fitterer PH (1998) Description and comparison of major foregut ossicles in hydrothermal vent crabs. Mar Biol 131:259-267

Mattson WJ (1980) Herbivory in relation to plant nitrogen content. Ann Rev Ecol Syst. doi:10.1146/annurev.es.11.110180.001003

Micheli F, Peterson CH, Mullineaux LS, Fisher CR, Mills SW, Sancho G, Johnson GA, Lenihan HS (2002) Predation structure communities at deep-sea hydrothermal vents. Ecol Monogr 72(3):365-382

Ngoc-Ho N (1984) The functional anatomy of the foregut of Porcellana platycheles and compatison with Galathea squamifera and Upogebia deltaura (Crustacea: Decapoda). J Zool Lond 203:511-535

Nickell LA, Atkinson RJ (1995) Functional morphology of burrows and trophic modes of three thalassinidean shrimp species, and a new approach to the classification of thalassinidean burrow morphology. Mar Ecol Prog Ser. doi:10.3354/rstb.1984.0081

Nickell LA, Atkinson RJA, Pinn EH (1998) Morphology of thalassinidean (Crustacea: Decapoda) mouthparts and pereiopods in relation to feeding, ecology and grooming. J Nat Hist. doi:10.1080/ 00222939800770381

Oxley AP, ShiptonW, Owens L, McKay D (2002) Bacterial flora from the gut of the wild and cultured banana prawn, Penaeus merguiensis. J Appl Microbiol. doi:10.1046/j.1365-2672.2002.01673.x

Pailleret M, Haga T, Petit P, Gill CP, Saedlou N, Gaill F, Zbinden M (2006) Sunken wood from the Vanuatu Islands: identification of wood substrates and preliminary description of associated fauna. Mar Ecol. doi:10.1111/j.1439-0485.2006.00149.x

Palacios C, Zbinden M, Baco AR, Treude T, Smith C, Gaill F, Lebaron P, Boetius A (2006) Microbial ecology of deep-sea sunken woods: quantitative measurements of bacterial biomass and cellulolytic activities. Cah Biol Mar 47:415-420

Phillips NW (1984) Role of different microbes and substrates as potential suppliers of specific, essential nutrients to marine detritivores. Bull Mar Sci 35:283-298

Phleger CF, Nelson MM, Groce AK, Cary SC, Coyne KJ, Nichols PD (2005) Lipid composition of deep-sea hydrothermal vent tubeworm Riftia pachyptila, crabs Munidopsis subsquamosa and Bythograea thermydron, mussels Bathymodiolus sp. and limpets Lepetodrilus spp. Comp Biochem Physiol B Biochem Mol Biol 141:196-210

Pillai SR (1960) Studies on the shrimp Caridina laevis Heller. 1. Digestive system. J Mar Biol Assoc India 2:57-75

Pinn EH, Nickell LA, Rogerson A, Atkinson RJA (1999) Comparison of gut morphology and gut microflora of seven species of mud shrimp (Crustacea: Decapoda: Thalassinidea). Mar Biol. doi: $10.1007 / \mathrm{s} 002270050448$

Plante C, Jumars PA, Baross JA (1990) Digestive associations between marine detritivores and bacteria. A Rev Ecol Syst 21:93-127

Potrikus CJ, Breznak JA (1977) Nitrogen-fixing Enterobacter agglomerans isolated from guts of wood-eating termites. Appl Environ Microbiol 33(2):392-399

Powell RR (1974) The functional morphology of the fore-guts of the thallassinid crustaceans, Callianassa californiensis and Upogebia pugettensis. University of California Press, Berkeley

Reynolds JD, O'Keeffe C (2005) Dietary patterns in stream- and lakedwelling populations of Austropotamobius pallipes. Bull $\mathrm{Fr}$ Peche Piscicult 376-377:715-730 
Salindeho IR, Johnston DJ (2003) Functional morphology of the mouthparts and proventriculus of the rock crab Nectocarcinus tuberculosus (Decapoda: Portunidae). J Mar Biol Assoc UK 83:821-834

Samadi S, Dupont J, Rousseau F, Haga T, Amos G, Richer de Forges B (2005) Campagne BOA1 du N.O. «Alis» au Vanuatu du 2 au 18 septembre 2005, $10 \mathrm{p}$

Samadi S, Quéméré E, Lorion J, Tillier A, Cosel R, Lopez P, Cruaud C, Couloux A, Boisselier M-C (2007) Phylogenetic position of sunken woods mytilids. C R Biol 330(5):446-456

Schembri PJ (1982) Functional morphology of the mouthparts and associated structures of Pagurus rubricatus (Crustacea: Decapoda: Anomura) with special reference to feeding and grooming. Zoomorphology 101:17-38

Schwarz JR, Yayanos AA, Colwell RR (1976) Metabolic activity of the intestinal microflora of a deep-sea invertebrate. Appl Environ Microbiol 31:46-48

Skilleter GA, Anderson DT (1986) Functional morphology of the chelipeds, mouthparts and gastric mill of Ozius truncates (Milne Edwards) (Xanthidae) and Leptograpsus variegatus (Fabricius) (Grapsidae) (Brachyura). Aust J Mar Freshw Res 37:67-79

Skov MW, Hartnoll RG (2002) Paradoxical selective feeding on a lownutrient diet: why do mangrove crabs eat leaves? Oecologia 131:1-7

Smith DC, Douglas AE (1987) The biology of symbiosis. Edward Arnold Ltd, London

Smith CR, Kukert H, Wheatcroft RA, Jumars PA, Deming JW (1989) Vent fauna on whale remains. Nature 341:27-28

Smith CR, Baco AR, Hannides A, Ruplinger D (2003) Chemosynthetic habitats on the California slope: whale-, wood- and kelp-falls compared to vents and seeps. Biogeography and Biodiversity of Chemosynthetic Ecosystems: Planning for the Future Southampton Oceanography Centre, Southampton, UK

Stamhuis EJ, Dauwe B, Videler JJ (1998) How to bite the dust: morphology, motion pattern and function of the feeding appendages of the deposit-feeding thalassinid shrimp Callianassa subterranea. Mar Biol 132:43-58

Turner RD (1977) Wood, mollusks and deep-sea food chains. Bull Am Malacol Union 213:13-19

Van Dover CL, Lichtwardt RW (1986) A new trichomycete commensal with a galatheid squat lobster from deep-sea hydrothermal vents. Biol Bull 171(2):461-468

Wafar S, Untwale AG, Wafar M (1997) Litter fall and energy flux in a mangrove ecosystem. East Coast Shelf Sci. doi:10.1006/ecss. 1996.0152
Warner GF (1977) The biology of crabs. Elek Science, London, UK

Webster JR, Benfield EF (1986) Vascular plant breakdown in freshwater ecosystems. Annu Rev Ecol Syst 17:567-594

Werner D, Barea JM, Brewin NJ, Cooper JE, Katinakis P, Lindstrom K, O'Gara F, Spaink HP, Truchet G, Muller P (2002) Symbiosis and defence in the interaction of plants with microorganisms. Symbiosis 32:83-104

Williams AB (1988) New marine decapod crustaceans from waters influenced by hydrothermal discharge, brine, and hydrocarbone seepage. Fish Bull 86(2):263-287

Williams AB, Smith CR, Baco AR (2000) New species of Paralomis (Decapoda, Anomura, Lithodidae) from a sunken whale carcass in the San Clemente basin off southern California. J Crust Biol 20(special number 2):281-285

Wolcott DL, O'Connor NJ (1992) Herbivory in crabs: adaptations and ecological considerations. Am Zool. doi:10.1093/icb/32.3.370

Wolcott DL, Wolcott TG (1984) Food quality and cannibalism in the red crab Gecarcinus lateralis. Physiol Zool 57:318-324

Wolfe SH, Felgenhauer BE (1991) Mouthpart and foregut ontogeny in larval, postlarval, and juvenile spiny lobster, Panulirus argus Latreille (Decapoda, Palinuridae). Zool Scripta. doi:10.1111/ j.1463-6409.1991.tb00274.x

Wolff T (1979) Macrofaunal utilization of plant remains in the deep sea. Sarsia 64:117-136

Wu MF, Chan TY, Yu HP (1998) On the Chirostylidae and Galatheidae (Crustacea: Decapoda: Galatheidea) of Taiwan. Annu Taiwan Mus 40:75-153

Zbinden M, Cambon-Bonavita M (2003) Occurrence of Deferribacterales and Entomoplasmatales in the deep-sea Alvinocarid shrimp Rimicaris exoculata gut. FEMS Microbiol Ecol. doi:10.1016/ S0168-6496(03)00176-4

Zimmer M, Bartholmé S (2003) Bacterial endosymbionts in Asellus aquaticus (Isopoda) and Gammarus pulex (Amphipoda) and their contribution to digestion. Limnol Oceanogr 48(6):2208-2213

Zimmer M, Topp W (1998) Microorganisms and cellulose digestion in the gut of the woodlouse Porcellio scaber. J Chem Ecol 24(8):1397-1408

Zook D (1998) A new symbiosis language. ISS Symbiosis News 1(3):1-3

Zurek L, Keddie BA (1998) Significance of methanogenic symbionts for development of the American cockroach, Periplaneta americana. J Insect Physiol. doi:10.1016/S0022-1910(98)00024-9 